\title{
Manufacture and Performance Evaluation of Machine to Extend Plastic Films Under Soil Surface to Improve Water Retention Balouza-North Sinai
}

\author{
Adil Abdelsamia Meselhy \\ Agricultural Mechanization Unit, Soil and Water Conservation Department - Desert Research Center, Cairo, Egypt \\ Email address: \\ adil_meselhy@yahoo.com \\ To cite this article: \\ Adil Abdelsamia Meselhy, Manufacture and Performance Evaluation of Machine to Extend Plastic Films Under Soil Surface to Improve \\ Water Retention Balouza-North Sinai. International Journal of Applied Agricultural Sciences. Vol. 6, No. 5, 2020, pp. $148-161$. \\ doi: $10.11648 /$ j.ijaas.20200605.16
}

Received: September 12, 2020; Accepted: September 25, 2020; Published: October 13, 2020

\begin{abstract}
Water shortage presents a serious problem nowadays. This problem will certainly worsen in the future, and so, improving the irrigation water efficiency by various methods is one of the economically viable alternatives in overcoming the water scarcity. It considers a good solution to overcome the fight against famine especially in the developing countries. A new technique in cultivation by installing plastic membrane sheet below the crop's root zone named subsurface water retention technology (SWRT) which helped to save irrigation water in the root zone, less farm losses, increasing the field water use efficiency and water productivity. But the difficult of installing SWRT system alienated many farmers from adopting this system. Therefore, in this paper, developed machine was manufactured to install the plastic membrane sheet below the root zone of Faba bean crop during the winter growing season 2018 in open field which cultivated at two systems, the first was ridges system and the second was flat soil system. The total fabrication cost of the study machine was $25000 \mathrm{~L}$. E with 2018 price level. This research was carried out in a Balouza research station in north Sinai governorate. Subsurface drip irrigation system was used for irrigation process and laid by developed machine. Three treatments types were used, cultivated system treatment (ridges and flat soil), aspect ratio treatment (2:1, 3:1 and 4:1) (width to height) and the installing depth of plastic sheet from soil surface $(20,30$ and 40$) \mathrm{cm}$. In addition, control treatment was without using the plastic membrane sheet. Actual field capacity, field efficiency, pulling force, fuel consumption rate, total water stored, water consumptive use, stored and consumption water efficiency, Faba bean grain yield, productivity of irrigation water, cost of developed machine and cost of manual process were discussed and compared between the treatments. The obtained results indicated that the machine study succeed in carried out SWRT system and laying subsurface drip irrigation pipes at efficiency of $92 \%$ for plastic laying depth, $(91 \%-95 \%)$ for plastic aspect ratio (width - height) and $96 \%$ for depth of laying drip pipes. In general, SWRT system achieved the highest total water stored, water consumptive use and Faba bean grain yield about of $49 \%$, 53\% and $50 \%$ respectively, and achieved the lowest cost about of $74 \%$ compared to without using plastic film. The results showed that aspect ratio 2:1 achieved the lowest pulling force, fuel consumption and cost about of $24 \%, 22 \%$ and $7 \%$ respectively, and the highest actual field capacity about of $6 \%$ compared to $4: 1$ aspect ratio. While, the aspect ratio $4: 1$ achieved the highest total water stored, water consumptive use and Faba bean grain yield about of $21 \%, 26 \%$ and $14 \%$ respectively, compared to $2: 1$ aspect ratio. The lowest pulling force, fuel consumption and cost achieved at $20 \mathrm{~cm}$ plastic laying depth about of $49 \%, 44 \%$ and $8 \%$ respectively, and highest actual field capacity about of $6 \%$ compared to $40 \mathrm{~cm}$ depth. The highest total water stored, water consumptive use and Faba bean grain yield about of $14 \%, 17 \%$ and $11 \%$ respectively, at $40 \mathrm{~cm}$ plastic laying depth compared to $20 \mathrm{~cm}$ depth. The ridge system achieved the lowest pulling force, fuel consumption and cost about of $33 \%, 32 \%$ and $8 \%$ respectively, and the highest actual field capacity, total water stored, water consumptive use and Faba bean grain yield about of $5 \%, 8 \%, 9 \%$ and $8 \%$ respectively, compared to flat soil.
\end{abstract}

Keywords: Faba Bean Crop, Moisture Conservation, Subsurface Drip Irrigation, Subsurface Water Retention Technology 


\section{Introduction}

The utilization modern technology that named subsurface water retention technology (SWRT) led to improve the cultivation in the soils that have light texture by installation the membrane in the root zone. This membrane keeps the water and nutrient over the membrane and prevents the lost water by deep percolation. Increasing frequencies of drought coupled with increasing populations require more water for irrigated agriculture. As global populations approach 9 billion by 2050 , even more water will be required to produce an estimated $60 \%$ to $70 \%$ more food [1]. Production of these greater quantities of food requires, at current water use efficiency rates, $50 \%$ more water [2]. The main problems of sandy soil are moisture holding capacity and nutrients deficiency and clay soils holding high moisture content, but water use efficiency at the interface of Field Capacity and Permanent Wilting Point is maintained with little suction in sandy soils. Therefore, the sandy soils can be very productive if the water is to be managed wisely [3]. Subsurface trickle irrigation water provision of $35 \%$ to $55 \%$ were probable compared to conventional irrigation forms like sprinkler and furrow irrigation systems. Also using subsurface trickle irrigation system together with the soil water retention technology (SWRT) improving crop yield, field water use efficiency of cucumber plant and the value of saving in applied of irrigation water [4]. As the population increases and increases the use of water in urban areas, irrigated cultivation is being called to output more nourishment utilizing least water, and implementing it without deterioration the soil and the water resources [5]. Plastic films buried $40 \mathrm{~cm}$ below the soil surface achieved significantly increased spring wheat yield by improving the soil water content and temperature in the topsoil [6]. Installing SWRT below the root zone resulted in increased water-holding capacity when applied in sandy soil by $23 \%$ to $95 \%$ depending on the amount of water processed. Improving the efficiency of irrigation water by different methods is one of the economically viable alternatives in overcoming the water scarcity [7]. Sandy soils will be very productive when water is wisely managed both above and within the soil. Consequently, subsurface water retention technology (SWRT) is a promising solution to overcome the fight against hunger especially in the developing countries [8]. The development of non-traditional new technologies to conserve water is becoming important for attaining a sustainable economic growth, especially in agricultural countries [9]. This is not only crucial for the sustainable agricultural yield but also to meet the challenges of current environmental issues and justice, financial problems and physical barriers in the developing countries [10]. SWRB system showed that low frequency drainage holes in polyethylene (PE) membranes within sand columns retained much more water than control treatments yet drained gravitational water when soil became saturated [11]. The influence of soil water retention barriers (SWRB) and irrigation levels effect on soil moisture content, perennial ryegrass moisture consumption and on fresh yield.
They installed SWRT at two various soil depths 30 and 40 $\mathrm{cm}$, and three various irrigation levels of 100, 66 and $33 \%$ of available water-holding capacity are used in sandy soil. The results show that when SWRT installed at depth $40 \mathrm{~cm}$ together with $34 \%$ water deficit save $52 \%$ of irrigation water compared with no SWRT is used [12]. One of the utilizing methods and saving the applied irrigation water is the use of soil water retention technology (SWRT) along with the surface and subsurface trickle irrigation system. SWRT can keep water and nutrients, and it saves up to $50 \%$ of the water and fertilizers added in agricultural land [13]. SWRT is a water-saving membrane made of low-density polyethylene (LDPE), and that is installed as U-shaped beneath the root area of the plant with a particular aspect ratio (the ratio of width to height), leaving a proper space for root growth and ease of movement with internal drainage through excessive rainfall. A novel subsurface water retention technology (SWRT) dramatically reduced irrigation requirements by retaining at least $50 \%$ or more soil water in the plant root zone. Water-saving membranes reduced drought stress events even during the driest years. The SWRT water saving membranes also is designed to prevent flooding in the root zone of sandy soils [14]. The new subsurface water retention technology (SWRT) transforms lives and landscapes by retaining both soil water and nutrients in the root zone of food and cash crops in an environmentally sustainable manner that increases productivity, local economies while reducing soil erosion, input costs and environmental contamination of groundwater, and reduce soil salinity, increase irrigation efficiency, decrease irrigation frequency, improve crop yield, and reduce labor [15]. The performance of using membranes below the soil surface in sandy soil planted with corn. The result indicates an increase in corn production of about $238 \%$. The objectives of this study were to evaluate and compare the effects of subsurface watersaving membranes, installed at depth $35 \mathrm{~cm}$ below ground surface in a sandy loam soil, on yield $(\mathrm{Y})$ and water use efficiency (WUE) of eggplant inside the greenhouse. Subsurface soil water retention membranes, installed within plant root zones, comprise a self-regulating type of technology that improves the production of food and cellulosic biomass and increases water use efficiencies for the dramatic expansion of food, fiber, and cellulosic biomass production needed by the rapidly expanding global populations. It is anticipated that these water savings will also diminish the growing competition for water among regional and economic sectors [16]. Subsurface soil water retention membranes installed within plant root zones, comprise a self-regulating type of technology that improves the production of food and cellulosic biomass and increases water use efficiencies for the dramatic expansion of food and fiber production [17]. The optimal geometric parameters of the SWRT membranes and the most accurate irrigation rates for corn production in sandy soil studied. They setup subsurface water retention membrane in three depths: $20 \mathrm{~cm}$, $40 \mathrm{~cm}$, and $60 \mathrm{~cm}$, in large sand-filled lysimeter, with aspect ratios: 2:1, 3:1, 5:1 and 10:1 controlled by aspect ratios of 
SWRT membranes. Moreover, SWRT membrane with an aspect ratio of 2:1 basically increased soil moisture content at $20 \mathrm{~cm}$ soil layer above the membrane. The overall conclusion was that SWRT appeared to be an encouraging technology for precision water content in the plant root zone and for minimizing water and nutrient losses during deep infiltration [18]. Subsurface water retention technology (SWRT) is a new, long-term approach to improve water storage capacities especially in coarse soil texture for sustainable crop production, increasing in yield and water use efficiency. They found that the SWRT controls the soil water content in sandy soils at optimal levels for corn growth, diminish water loss through deep drainage and minimize total irrigation depths. SWRT consists of subsurface polyethylene membrane installed within the crop's root zone with a specific aspect ratio that prevents the loss of irrigation water via deep percolation [19]. The experiment is conducted in a lysimeter inside a greenhouse using six membrane of different geometry polyethylene sheet installed at four depths. Membrane with 2:1, 3:1 and 5:1 aspect ratio installed at depth 20 to $40 \mathrm{~cm}$ in sand, sandy loam and loamy sand soil textures. The results show that the highest reduction in water losses for most soil texture in the study case are achieve with a 2:1 aspect ratio (width to depth of the $U$ shape) membrane installed at depth $20 \mathrm{~cm}$. Moreover, the SWRT is sensitive to uncontrolled irrigation process. Additional tests are required for membrane performance in a field for different crops across a range of different climates conditions. They conclude that the increasing in crops yield by using SWRT film is due to double the soil moisture contents in the root zone of plants in coarse textured soil as shown in Figure 1 [20].

\section{SWRT}

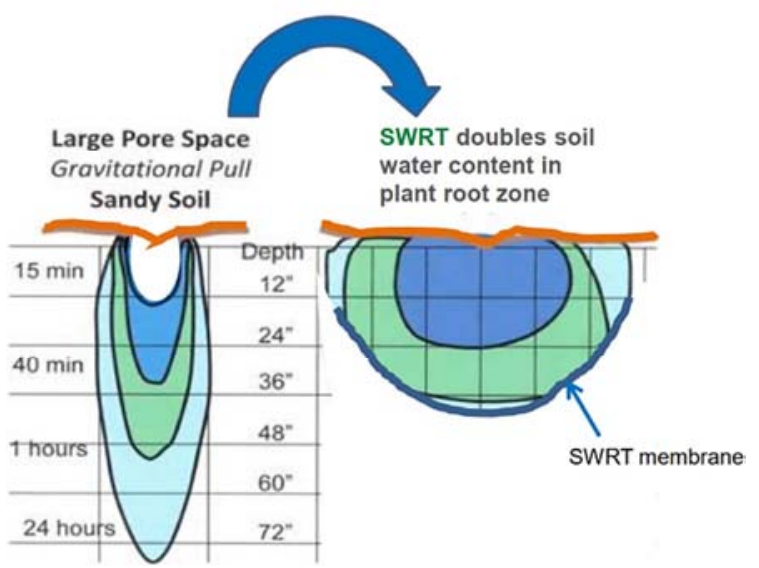

Figure 1. Double soil water content in plants root zone. Guber et al. (2015).

One of the modern techniques for developing water productivity is the use of soil water retention technology (SWRT) with trickle irrigation system (surface or subsurface). SWRT is a new technology to increase plant productivity by applying as little irrigation water as possible and thus improving water productivity [21]. The field experiment conducted to study the effect of the membrane sheet installed below the soil surface and under the root zone of the crop on yield and water use efficiency (WUE) of maize. The experiment was conducted inside a greenhouse and lysimeter was constructed. Sandy soil was used cultivated with maize. The results indicated that the soil water content above the membrane sheet was doubled the water holding capacity, increased maize production by $240 \%$ and increasing water use efficiency by $77 \%$ [22]. The field experiment was carried out to study the effect of installing the membrane sheet below the root zone on WUE of hot pepper and tomato crops in greenhouses. The experimental sites were located in Diyala and Najaf governorates utilize SWRT treatment plot, organic treatment plots, tillage treatment plots and no tillage treatment plots. The obtained results showed that the value of WUE of hot pepper in Diyala site with SWRT was more than other plots by 233. Additionally, the value of WUE of hot pepper in Najaf site was more than other plots by $165 \%$ [23]. The influence of SWRT on soil moisture content, frequency of watering and heat of the soil was studied. SWRT was set up at varies depths in sand texture of soil. The plant which utilized name the maize and utilized straw mulches cultivated on soil surface and without. The search was carried out in Kerman of Iran during the second month of 2013 to the last of eleventh month of 2014. The water and heat of soil was improved via using SWRT sheet and the irrigation frequency was calculated. Furthermore, SWRT sheet was appeared to be good influence on water retention for plant at all depths. They suggest using SWRT sheet with mulch to improve the condition of sandy texture soil [24]. The effect of using polyethylene sheet, organic matter, tillage and no-tillage on irrigation water use efficiency (IWUE) of hot pepper studied. The experiment was conducted in two fields sites located in Diyala and Najaf Cities. The results indicated that in Diyala field site, the IWUE value of hot pepper for SWRT plot is the highest value among organic matter; tillage and no-tillage by 106,167 and $135 \%$, respectively, and with saving in water almost have of the quantity applied. Additionally, the IWUE for hot pepper in Najaf field site is also the highest value by 38,79 and $89 \%$, respectively, and with saving in water almost 33\% [25]. The using of the membrane sheet below hot pepper and okra crop's root zone on water use efficiency and water productivity evaluated. The experimental work was carried out in two different sites in the growing seasons 2016 and 2017, in Sadat Al-Hindyia, Babylon of Iraq. Surface trickle irrigation system was used in the irrigation process inside the greenhouses. The obtained results indicated that clear increasing values of WUE and WP in the treatment plot with membrane sheet were observed. The value of WUE of hot pepper and okra was more than other plots by an average value of $54 \%$ and $25 \%$, respectively. Moreover, the economic WP of hot pepper and okra in the plot of membrane sheet was more than other plots by an average value of $89 \%$ and $108 \%$, respectively [26]. The field water use efficiency of eggplant was increased when membrane sheet was installed below the root zone of eggplant. The experiment was conducted inside greenhouse and in open field of the growing seasons 2016 and 2017. The research work was located north east of Baghdad. Two treatment plots were used; plot T1 with 
installing membrane sheet and plot T2 without using the membrane sheet. Sandy loam soil was used. The obtained results showed that FWUE of eggplant in the first and second season by 50 and 41\%, respectively [27]. Applying of SWRT below the ground surface on yield and water use efficiency of eggplant cultivated inside the greenhouse. The obtained results showed that yield and water use efficiency were improved by $6 \%$ and $52 \%$ in plot with applying the membrane trough comparing with plot without installing the membrane trough. Moreover, saving in the total of applied water was $44 \%$. Additionally [28]. Effect of SWRT on water use efficiency and economic water productivity for hot pepper cultivated inside the greenhouse in the growing season 2016-2017 evaluated. Three plots were used T1 (with SWRT), T2 (organic material) and T3 (tillage) in City of Babylon. The obtained results showed that the increasing value of yield and water use efficiency in plot T1 was more than T2 and T3 by $19.42 \%$, $26.87 \%$ and $50 \%, 59 \%$, respectively. Accordingly, economic water productivity in plot T1 was more than plots $\mathrm{T} 2$ and $\mathrm{T} 3$ by $81.7 \%$ and $97.1 \%$, respectively. Moreover, water use efficiency and water productivity for okra crop cultivated inside the greenhouse was also improved when membrane trough was installed within the root zone. The obtained results showed that the water use efficiency and water productivity was increased well in plot with installing the membrane trough by $148 \%$ and $170 \%$, respectively comparing with plot without applying the SWRT [29]. The effect of installing the membrane trough below the crop's root zone on field water use efficiency and economic water productivity of zucchini during summer season 2017 in open field studied. Two plots were used for the comparison T1 (with the membrane) and T2 (without the membrane). The obtained results showed that an increasing value of field water use efficiency in plot T1 was $30.2 \%$ comparing with plot T2. Additionally, increasing value in economic water productivity in plot $\mathrm{T} 1$ was $36.5 \%$ comparing with plot T2 [30].

Faba bean (Vicia faba L.) is one of the most important food legume crops as a source of plant protein and for its constitution in different popular delicious Egyptian food. Also, faba bean could be harvested in on immature condition to be eaten and cooked as green bean, in addition, straw yield of faba bean is national interest since great quantities are needed for animal feeding [31]. Faba bean (Vicia faba L.) is considered one of the most important pulse crops in Egypt. It has become one of the most important strategic crops due to its net income to the farmers. Also, cultivation of faba bean is important for soil fertility, human nutrition and as a good source of protein, for animal feeding and industry purposes [32]. Faba bean (Vicia faba L.) is the most important legume crop in Egypt, due to its high nutritive value for human being food, also it plays an integral part in animal feeding and its role break crop in cereal rotation system. The cultivated area was about 216,000 feddans in the last five seasons with an average seed yield of 9.0 ardeb/fed. In Northern part of Egypt, the planted area represents about $85 \%$ of the total planted faba bean area [33, 34].

The objectives of this study were manufacturing a machine to install plastic membrane sheet below the root zone of crops. Also, implement the field experiment to evaluate the both of machine performance and effect of subsurface water retention technology (SWRT) on improving the values of Faba bean grain yield and field water use efficiency.

\section{Materials and Methods}

\subsection{Field Conditions and Site of the Research Study}

The research study was carried out on sandy soil at Balouza research station of desert research center, north Sinai governorate Egypt. The latitude was equal $31^{\circ} 03^{\prime} \mathrm{N}$, longitude $32^{\circ} 36^{\prime} \mathrm{E}$ and $22 \mathrm{~m}$ altitude. Texture, physical and chemical properties of the studied soil presented in Tables 1 and 2.

Table 1. Soil texture of studied soil.

\begin{tabular}{lllll}
\cline { 1 - 3 } \multicolumn{2}{l}{ Particle size distribution (\%) } & & & $\begin{array}{l}\text { Texture of } \\
\text { soil }\end{array}$ \\
\cline { 1 - 4 } Coarse sand & Fine sand & Silt & Clay & Sand \\
\hline 42.26 & 43.28 & 13.28 & 1.18 & \\
\hline
\end{tabular}

Table 2. Physical and chemical properties of studied soil.

\begin{tabular}{lllll}
\hline $\begin{array}{l}\text { Bulk Density } \\
\mathbf{g} / \mathbf{c m}^{3}\end{array}$ & $\mathrm{CaCO}_{\mathbf{3}} \mathbf{g} / \mathbf{k g}$ & $\begin{array}{l}\text { Organic matter } \\
\mathbf{g} / \mathbf{k g}\end{array}$ & $\mathbf{E C ~ d s / \mathbf { m }}$ & $\mathbf{p H}$ \\
\hline 1.67 & 6.15 & 3.25 & 2.95 & 7.89 \\
\hline
\end{tabular}

\subsection{Treatments, Experimental Design and Crop Material}

This experiment included eighteen treatments, which were the combinations of two types of Faba bean cultivated systems (ridges and flat soil), three levels of plastic aspect ratio (2:1, $3: 1$ and $4: 1$ ) (width to height) and three levels of installing depth of plastic sheet from soil surface $(20,30$ and 40$) \mathrm{cm}$ as shown in Figures 2 and 3. In addition, control treatment without using the plastic membrane sheet. The treatments were arranged in a split-split plot design with three replicates. The plastic membrane sheet of thickness $100 \mu \mathrm{m}$ was installed below the soil surface under the root zone of Faba bean crop as U shape. Subsurface drip irrigation pipes laying at $15 \mathrm{~cm}$ depth from soil surface by study machine. Faba bean (Vicia faba L. Giza 716) was obtained from field crops research institute, Agricultural Research Center (ARC), Giza, Egypt. Faba bean seeds were sowed in winter season (November 2018 to April 2019) at a rate of (140 kg seeds/ha). Faba bean plants were harvested after 140 days.

\subsection{The Specifications of Manufactured Machine}

The machine designed and manufactured to perform a number of operations at the same time as follows:

1. Digging the soil to the required depth and forming the bottom of the digs with the required dimensions.

2. Installing the plastic films on the bottom of the digs.

3. Extending drip irrigation pipes to the required depth below the soil surface.

4. Filling digs and leveling the soil surface to cultivate Faba bean crop on flat soil.

5. 5- Filling the digs and forming the ridges to cultivate Faba bean crop on it. 
Constructional details of the machine for laying both plastic film and drip irrigation pipes under soil surface and seed-bed preparation of the soil to cultivate Faba bean crop on flat soil and ridges discussed as the following:

\subsubsection{Main Frame}

The main frame manufactured from $100 \mathrm{~mm}$ L shapes iron. The overall dimensions of the main frame were $2000 \mathrm{~mm}$ in length, $1500 \mathrm{~mm}$ in width and $1000 \mathrm{~mm}$ height. All parts of machine like, three points hitching system manufactured from $20 \mathrm{~mm}$ thickness iron at height of upper hitch point of $600 \mathrm{~mm}$ and lower hitch point spread of $600 \mathrm{~mm}$, one digger with shank (20 mm thickness and $70 \mathrm{~mm}$ width) and side board to format the bottom of the digs, press wheel, plastic roll carrier unit and drip irrigation pipes roll carrier unit were mounted on the main frame by welding or by using nuts and bolts. The dimensions and parts of developed machine presented in Figure 4.

\subsubsection{Digger}

The machine is equipped with one a changeable side board to form the digs at the required dimensions. The height of the digger is adjustable. as shown in Figure 5.

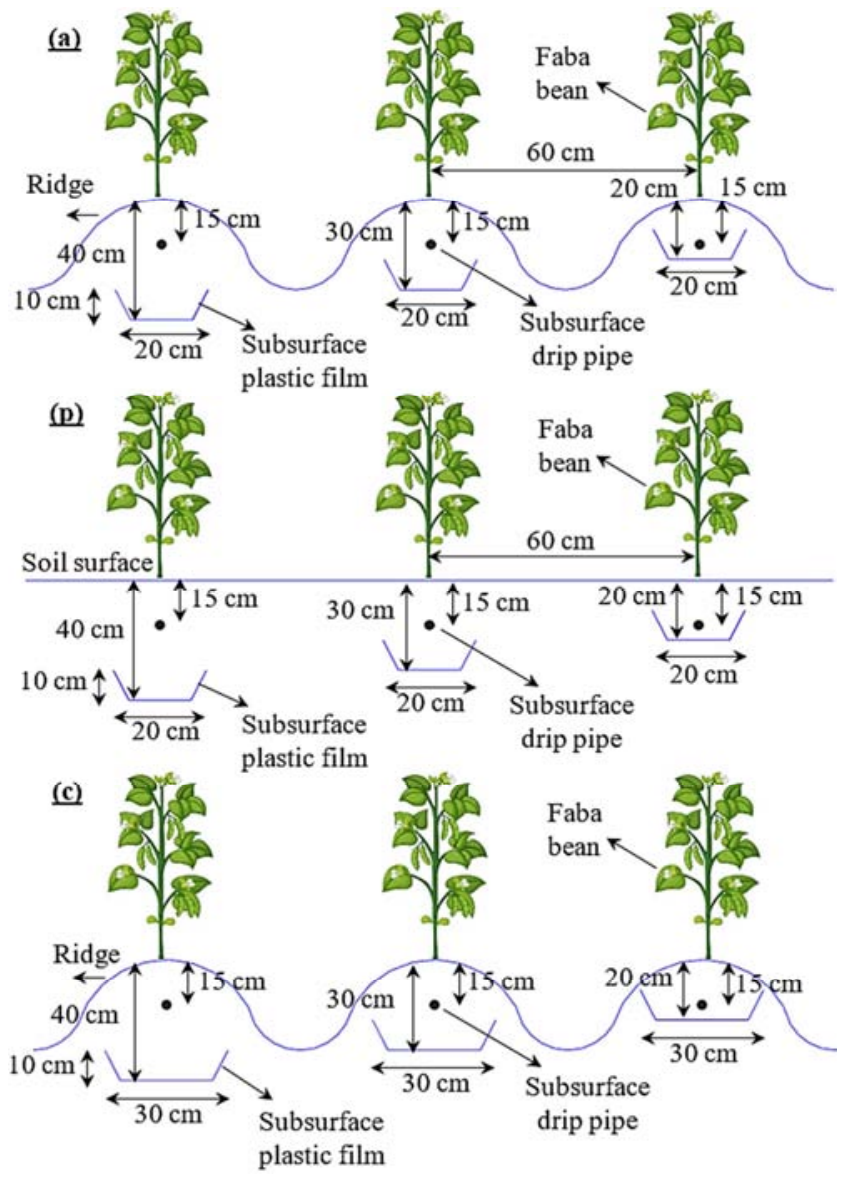

Figure 2. The study treatments. a-cultivated Faba bean on ridge, installing plastic film at (20,30 and 40) cm depth and aspect ratio 2:1. b-cultivated Faba bean on flat soil, installing plastic film at (20, 30 and 40) $\mathrm{cm}$ depth and aspect ratio 2:1. c-cultivated Faba bean on ridge, installing plastic film at (20,30 and 40) $\mathrm{cm}$ depth and aspect ratio 3:1.

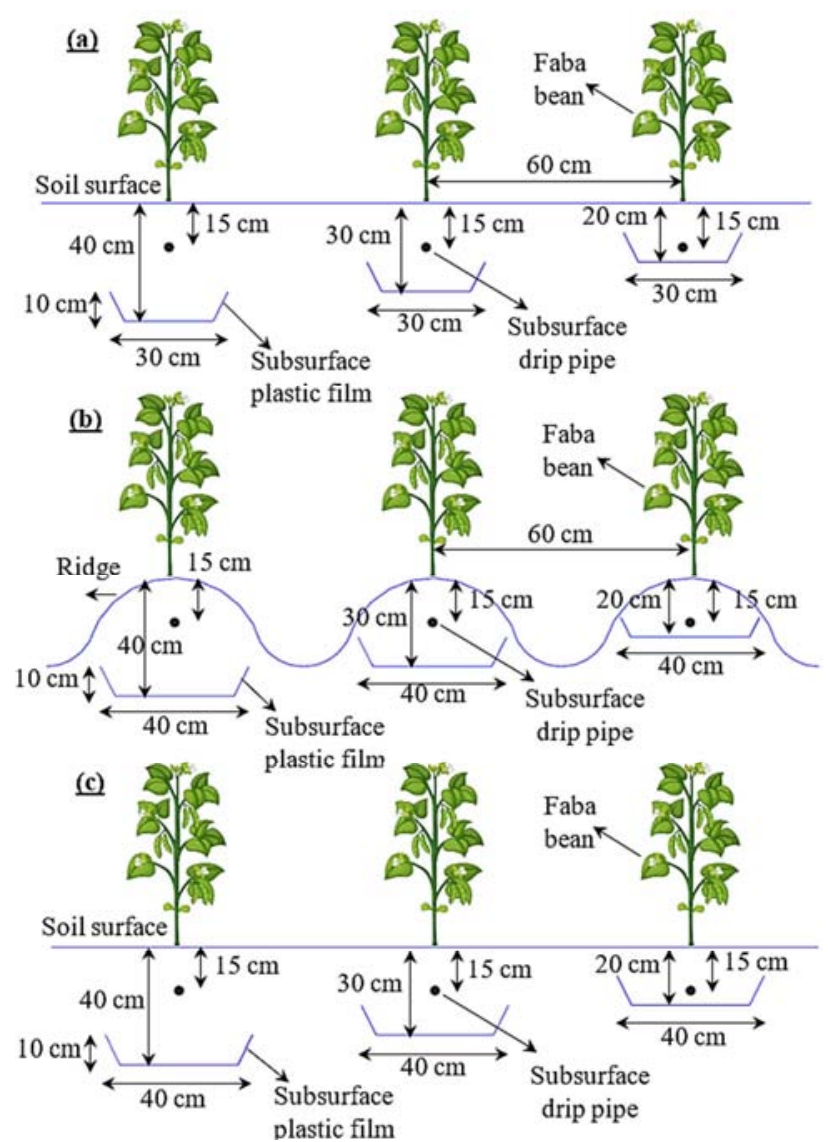

Figure 3. The study treatments. a- cultivated Faba bean on flat soil, installing plastic film at (20, 30 and 40) cm depth and aspect ratio 3:1. bcultivated Faba bean on ridge, installing plastic film at (20,30 and 40) cm depth and aspect ratio 4:1. c-cultivated Faba bean on flat soil, installing plastic film at (20,30 and 40) cm depth and aspect ratio 4:1.
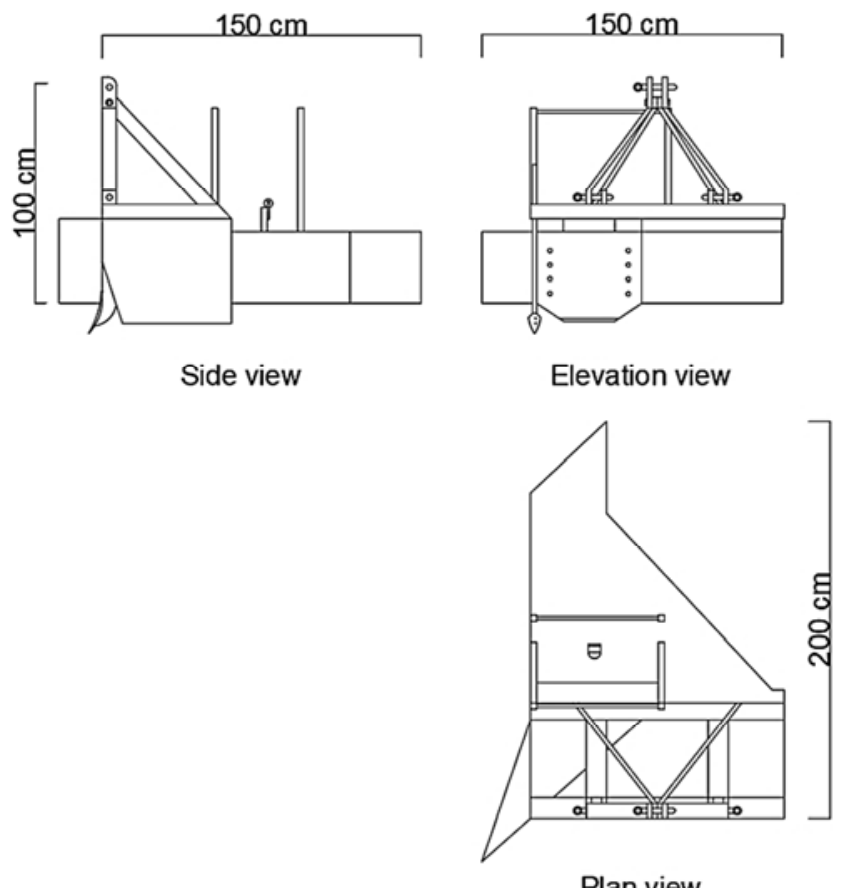

Plan view

Figure 4. Side, elevation and plan views of machine for installing plastic film and drip irrigation pipes under soil surface. 

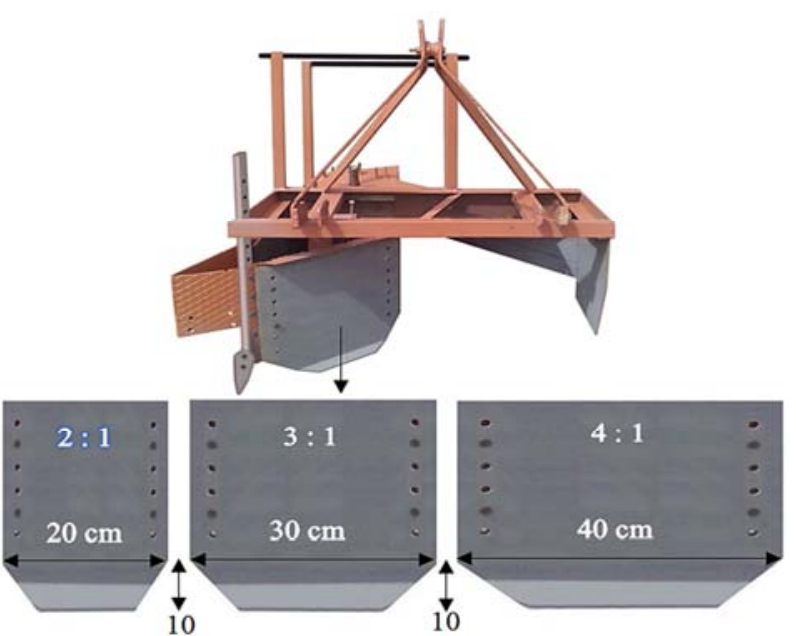

Figure 5. Types of digger boards to format bottom of digs at different aspect ratio.

\subsubsection{Press Wheel}

The operation of press wheel is to stretch the laid plastic film on the bottom of the digs so that it will not get displaced while in operation. The height of the press wheel is adjustable as shown in Figure 6.

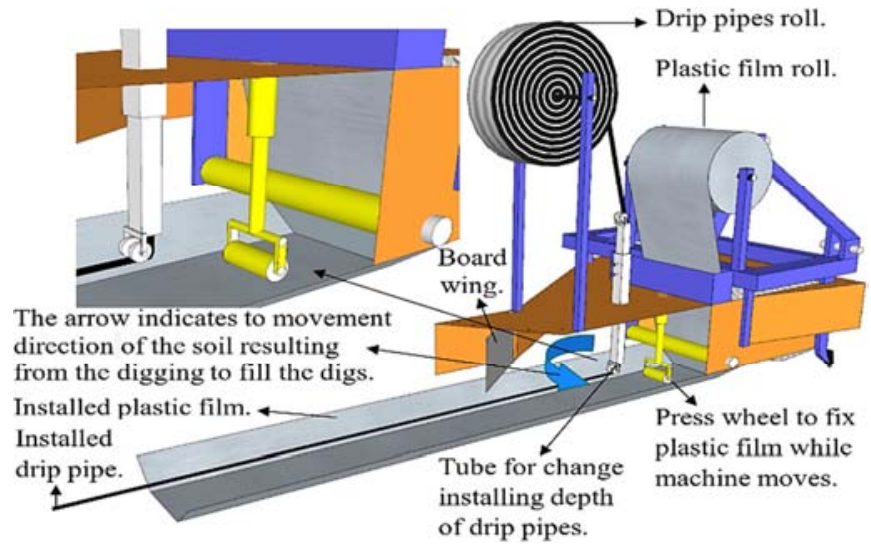

Figure 6. Study machine and mechanism of laying plastic film and drip irrigation pipes under soil surface.

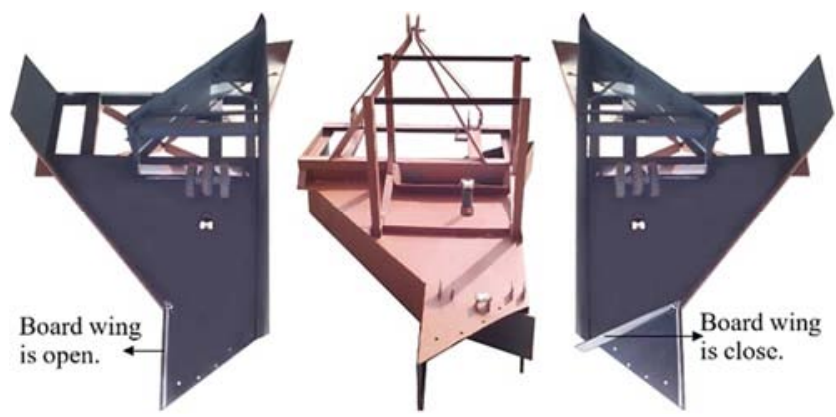

Figure 7. Open and close of board wing for the machine tail to prepare the soil surface in the form of flat or ridges.

\subsubsection{Board Wing}

A board wing at the end of the machine as shown in Figure 7 control the cultivation system to be applied (flat soil or ridges) by closing it to make the flat soil surface or opining it to make ridges as shown in Figures 8 and 9.

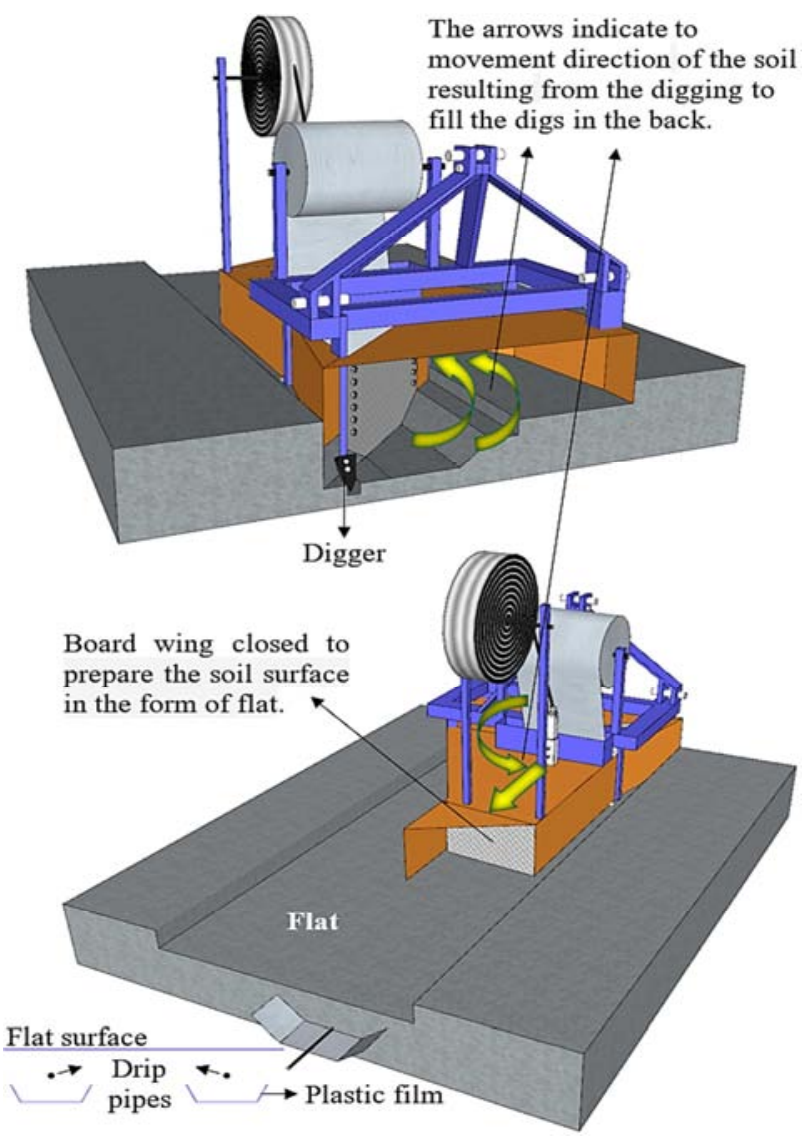

Figure 8. Prepare the soil surface in the form of flat by close board wing.

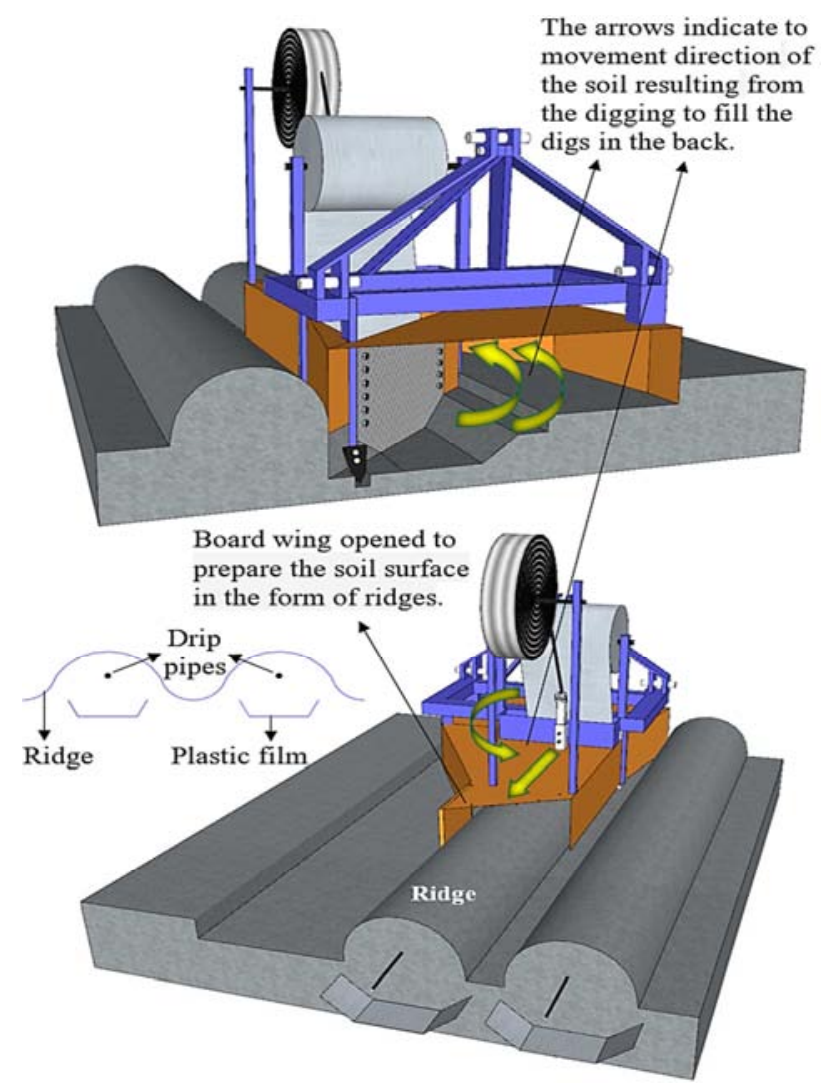

Figure 9. Prepare the soil surface in the form of ridges by open board wing. 


\subsubsection{Plastic Roll Carrier Unit}

The plastic roll has to be carried by a horizontal M. S. shaft perpendicular to direction of travel provided. A shaft was mounted in between the two bearing, which is used to roll the plastic film. The shaft was supported on the main frame. The plastic sheet has to be placed under the press wheel manually before starting of the plastic film laying operation. The plastic film rotated and started to unwound automatically when the machine moves forward and plastic film was laid under the soil surface as shown in Figure 10. The plastic film used is of 100-micron thickness and (400 $\mathrm{mm}, 500 \mathrm{~mm}$ and $600 \mathrm{~mm}$ ) width to make $U$ shapes in different aspect ratio $(2: 1,3: 1$ and 4:1) respectively.

\subsubsection{Drip Irrigation Pipes Roll Carrier Unit}

The drip irrigation pipes roll has to be carried by a horizontal M. S. shaft perpendicular to direction of travel provided. A shaft was mounted in between the two bearing which is used to roll the drip irrigation pipes. The shaft was supported on the main frame. The drip pipes have to be placed under dead weight manually before starting of the drip pipes laying operation. The drip pipes rotated and started to unwound automatically when the machine moves forward and drip pipes laid in the digs under soil surface at depth $15 \mathrm{~cm}$ (subsurface) as shown in Figure 11.

\subsection{Tractor}

Tractor used in this experiment was $90 \mathrm{hp}$ at $2300 \mathrm{rpm}$ 3192 CC MAHINDRA diesel engine model, 8000 4WD. Power take-off shaft 540-1000 rpm. Tractor weight $3249 \mathrm{~kg}$. Tires front $24 \times 11.5$ and rear $34 \times 16.9$. The tractor has 12 forward speed and 12 reverse speed. The tractor pulled developed machine at fixed forward speed $3.6 \mathrm{~km} / \mathrm{h}$ for all study treatments.

\subsection{Crop Water Requirements}

Crop water requirements calculated using the reference evapotranspiration $\left(\mathrm{ET}_{\mathrm{o}}\right)$ and the crop coefficients $\left(\mathrm{K}_{\mathrm{C}}\right)$ by the following equation:

$$
\mathrm{ETc}=\mathrm{ET}_{\mathrm{o}} * \mathrm{~K}_{\mathrm{C}}
$$

Where; $\quad \mathrm{ET}_{\mathrm{c}}=\mathrm{Crop} \quad$ Evapotranspiration $\quad(\mathrm{mm} /$ day $)$, $\mathrm{ET}_{\mathrm{o}}=$ Reference Evapotranspiration $(\mathrm{mm} /$ day $)$ and $\mathrm{Kc}=\mathrm{Crop}$ coefficients.

Represent the Reference Evapotranspiration $\left(\mathrm{ET}_{\mathrm{o}}\right)$ according to (Center Laboratory for Agricultural Climate), crop coefficients $(\mathrm{Kc})$ for Faba bean according to Andreas P. (2002) [35] as shown in Table 3.

Table 3. Growth stages, Reference evapotranspiration, crop coefficient and Crop Evapotranspiration of Faba bean crop.

\begin{tabular}{|c|c|c|c|c|c|}
\hline Growth stage & Duration, day & $\mathrm{ET}_{\mathbf{0}}, \mathrm{mm} / \mathrm{day}$ & $\mathbf{K}_{\mathbf{c}}$ & ETc, mm/day & Depth of water, $\mathrm{mm}$ \\
\hline Initial & 20 & 1.5 & 0.44 & 0.66 & 13 \\
\hline Dev. & 50 & 1.8 & 0.7 & 1.26 & 63 \\
\hline Mid-season & 55 & 2.4 & 1.1 & 2.64 & 145 \\
\hline Season end & 15 & 3.2 & 0.6 & 1.92 & 29 \\
\hline Total & 140 & 8.9 & 2.84 & 6.48 & 250 \\
\hline
\end{tabular}

Net irrigation requirement $\left(\mathrm{IR}_{\mathrm{n}}\right)$ is derived from the field balance equation:

$$
\mathrm{IR}_{\mathrm{n}}=\mathrm{ET}_{\mathrm{c}}-\mathrm{P}_{\mathrm{eff}}+\mathrm{LR}
$$

Where: $\quad \mathrm{IR}_{\mathrm{n}}=\mathrm{Net}$ irrigation requirement $(\mathrm{mm} /$ day $)$, $\mathrm{ET}_{\mathrm{c}}=$ Crop evapotranspiration ( $\mathrm{mm} /$ day), $\quad \mathrm{P}_{\text {eff }}=$ Effective dependable rainfall, $(\mathrm{mm} /$ day $)$ and $\mathrm{LR}=$ Leaching requirement (mm).

Gross irrigation requirements account for losses of water incurred during conveyance and application to the field.

$$
\mathrm{IR}_{\mathrm{g}}=\mathrm{IR}_{\mathrm{n}} / \mathrm{E}_{\mathrm{a}}
$$

Where: $\operatorname{IR}_{\mathrm{g}}=$ Gross irrigation requirements $(\mathrm{mm} /$ day $)$, $\mathrm{IR}_{\mathrm{n}}=\mathrm{Net}$ irrigation requirement $\left(\mathrm{mm} /\right.$ day) and $\mathrm{E}_{\mathrm{a}}=$ Overall irrigation efficiency (\%).

Therefore, total water applied with leaching requirement for Faba bean crop at drip irrigation system was $3360 \mathrm{~m}^{3} / \mathrm{ha}$.

\subsection{Measurements}

\subsubsection{Theoretical Field Capacity, Actual Field Capacity and Field Efficiency}

Theoretical field capacity, actual field capacity and field efficiency were calculated by using equations mentioned by kepner et al. (1978) [36].

\subsubsection{Fuel Consumption Rate}

Fuel consumption per unit time was determined by measuring the volume of fuel consumed during operation time. It was measured using the fuel meter equipment as shown in Figure 12 the length of line which marked by the marker tool on the paper sheet represents the fuel consumption. The fuel meter was calibrated prior and the volume of fuel was determined accurately.

\subsubsection{Pulling Force}

Pulling force for machine was measured by hydraulic dynamometer, which was, coupled between two tractors with the attaching machine to estimate its draught force. A considerable number of readings taken at a time interval 10 seconds to obtain an accurate average of draught force.

\subsubsection{Machine Efficiency for Laying Plastic Film and Drip Irrigation Pipes Under Soil Surface}

The machine efficiency for laying plastic film and drip irrigation pipes under soil surface evaluated by taking randomly selected $1 \mathrm{~m}$ of soil length after finished of laying plastic film and drip irrigation pipes under soil surface in many places from field as shown in Figure 13 and digs it for measuring average actual depth of plastic film and drip 
irrigation pipe under the soil surface and average actual aspect ratio (width to height) of plastic film with the help of measuring scale and using the following experimental formula to calculate the efficiency:

$\eta \mathrm{m}=($ Actual dimensions $/$ Theoretical dimensions $) 100$

Where: $\eta m=$ Machine efficiency for laying plastic film and drip irrigation pipe under soil surface, (\%), Actual dimensions $=$ Average actual depth of plastic film under the soil, average actual subsurface drip irrigation pipe depth and average actual aspect ratio (width to height) of plastic film, (cm) and Theoretical dimensions=Theoretical depth $(20,30$ and 40) $\mathrm{cm}$ of plastic film under the soil surface, subsurface drip irrigation pipe depth $(15 \mathrm{~cm})$ and average actual aspect ratio (width to height) $(20 \mathrm{~cm}: 10 \mathrm{~cm}, 30 \mathrm{~cm}: 10 \mathrm{~cm}$ and $40 \mathrm{~cm}$ : $10 \mathrm{~cm})$ of plastic film.

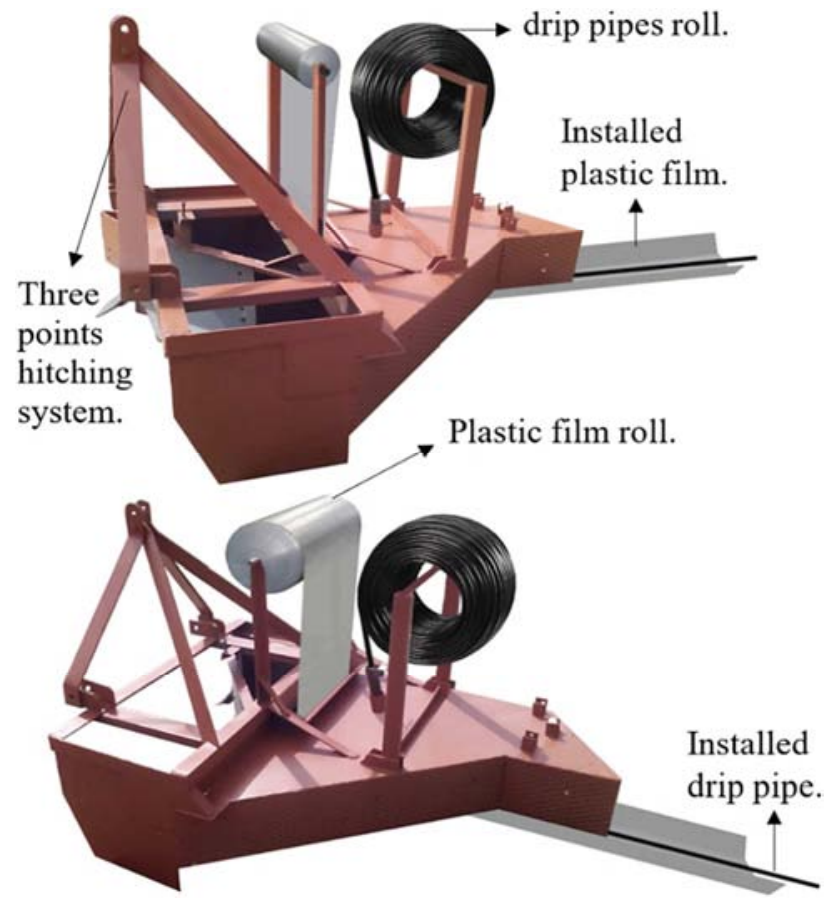

Figure 10. Plastic film roll and drip irrigation pipes roll of machine.

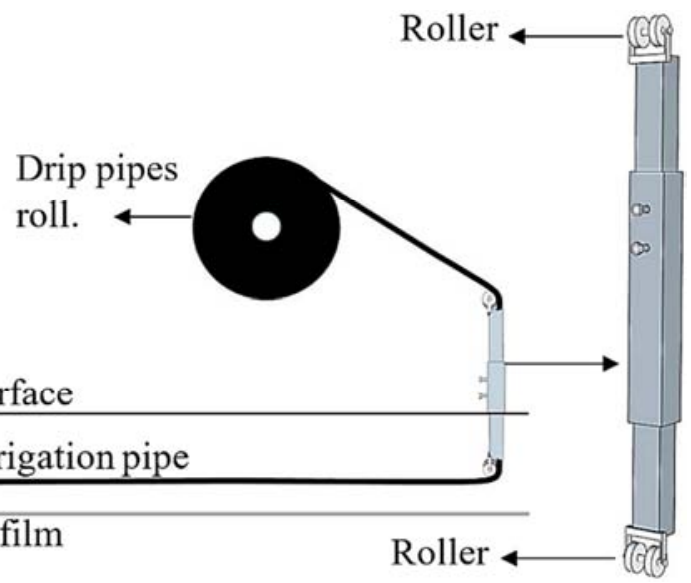

Figure 11. Mechanism of laying drip irrigation pipes under soil surface.
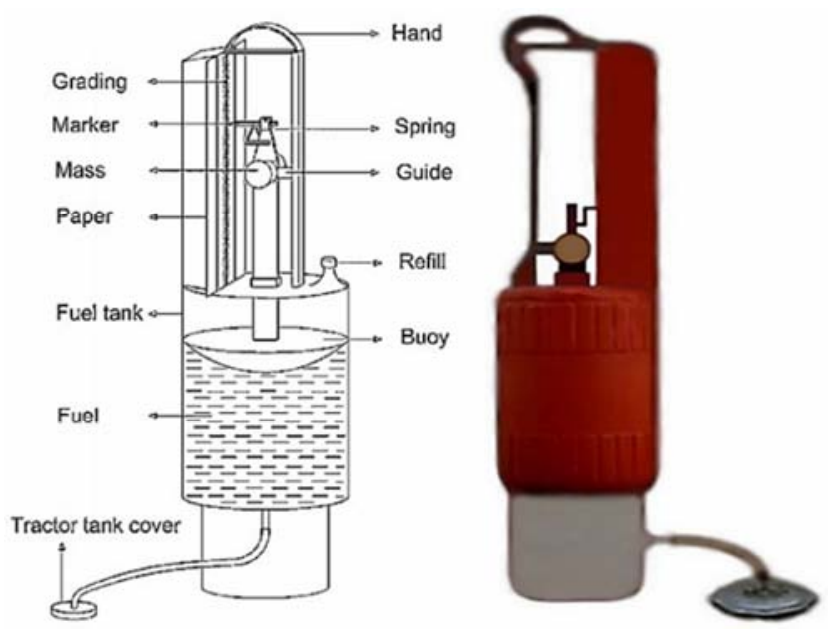

Figure 12. Fuel meter for measuring fuel consumption.

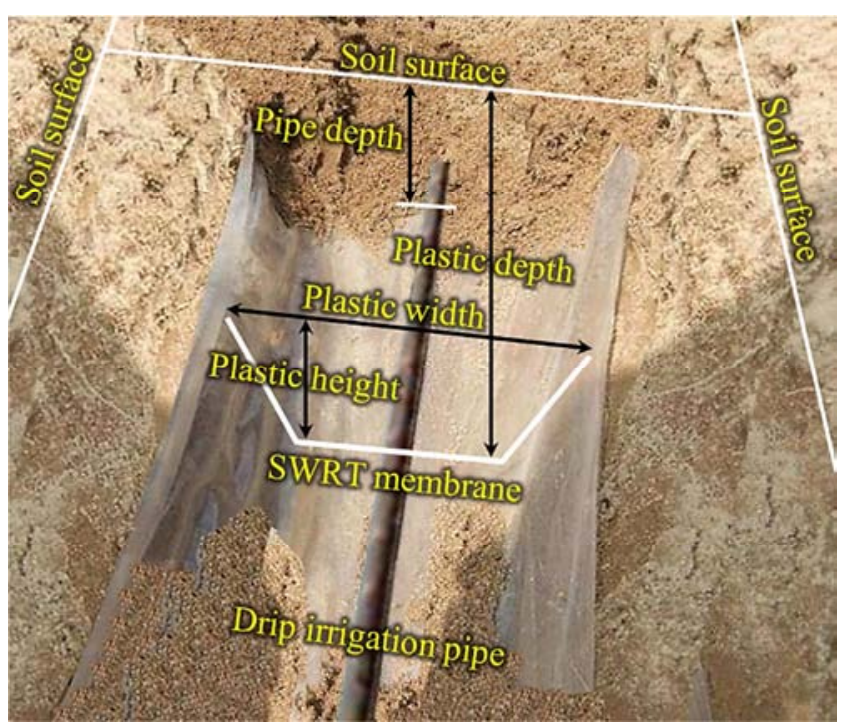

Figure 13. Plastic film and drip irrigation pipes installed under soil surface.

\subsubsection{Soil Moisture Content}

Soil moisture content in $0-60 \mathrm{~cm}$ soil layers at $15 \mathrm{~cm}$ was measured using a TDR 300 soil moisture meter (time domain reflector meter).

\subsubsection{Total Water Stored in the Effective Root Zone}

Water stored in the root zone was determined according to James (1988) [37] as follows:

$$
\text { TWS }=\sum_{\mathrm{i}=1}^{\mathrm{i}=4}\left(\frac{\theta_{\mathrm{fc}}-\theta_{\mathrm{wp}}}{100}\right) \mathrm{D}_{\mathrm{r}} * \rho_{\mathrm{b}}
$$

Where: TWS $=$ Water stored in the root zone, $(\mathrm{mm})$, $\Theta_{\mathrm{fc}}=$ Soil moisture content at field capacity, $(\%), \Theta_{\mathrm{wp}}=$ Soil moisture content at permanent wilting point, (\%), $\mathrm{D}_{\mathrm{r}}=$ Effective root depth, $(\mathrm{mm}), \rho_{\mathrm{b}}=$ Soil bulk density, $\left(\mathrm{g} / \mathrm{cm}^{3}\right)$ for depth and $i=$ Number of soil layers (1-4).

\subsubsection{Water Consumptive Use in Effective Root Zone}

Water consumptive use by growing plants was calculated based on soil moisture depletion (SMD) according to Hansen et al. (1979) [38]. 


$$
\mathrm{WCU}=\sum_{\mathrm{i}=1}^{\mathrm{i}=4}\left(\frac{\theta_{\mathrm{fc}}-\theta_{\mathrm{i}}}{100}\right) \mathrm{D}_{\mathrm{r}} * \rho_{\mathrm{b}}
$$

Where: WCU $=$ Water consumptive use in the effective root zone $(\mathrm{mm}), \Theta_{\mathrm{fc}}=$ Soil moisture content at field capacity, $(\%)$, $\Theta_{\mathrm{i}}=$ Soil moisture content before next irrigation, $(\%)$, $\mathrm{D}_{\mathrm{r}}=$ Effective root depth, $(\mathrm{mm}), \rho_{\mathrm{b}}=$ Soil bulk density, $\left(\mathrm{g} / \mathrm{cm}^{3}\right)$ for depth and $i=$ Number of soil layers (1-4).

\subsubsection{Water Efficiency and Productivity of Irrigation Water}

(i). Water Stored Efficiency

Water stored efficiency was calculated according to Israelsen and Hansen (1962) [39] as follows:

$$
\mathrm{WAE}=\left(\frac{\mathrm{TWS}}{\mathrm{TWA}}\right) * 100
$$

Where: WAE $=$ Water stored efficiency $(\%)$, TWS $=$ Total water stored in the effective root zone $\left(\mathrm{m}^{3} / \mathrm{ha}\right)$ and TWA $=$ Total water applied $\left(\mathrm{m}^{3} / \mathrm{ha}\right)$.

(ii). Water Consumptive Use Efficiency

Water consumptive efficiency was calculated according to Israelsen and Hansen (1962) as follows:

$$
\mathrm{ECU}=\left(\frac{\mathrm{TCU}}{\mathrm{TWA}}\right) * 100
$$

Where: ECU=Water consumptive efficiency (\%), TCU=Total water consumptive use in the effective root zone $\left(\mathrm{m}^{3} / \mathrm{ha}\right)$ and TWA $=$ Total water applied $\left(\mathrm{m}^{3} / \mathrm{ha}\right)$.

(iii). Productivity of Irrigation Water

Productivity of irrigation water (PIW) was calculated according to Ali et al. (2007) [40] as $\mathrm{kg}$ yield $/ \mathrm{m}^{3}$ water applied.

$$
\mathrm{PIW}=\frac{\mathrm{Y}}{\mathrm{I}}
$$

Where: $\mathrm{Y}=$ Faba bean crop yield $(\mathrm{kg} / \mathrm{ha})$ and $\mathrm{I}=$ Irrigation water applied $\mathrm{m}^{3} /$ ha.

\subsubsection{The Cost}

(i). Cost Analysis and Economical Evaluation

The cost analysis was calculated according to Oida, (1997) [41]. It was performed in two steps. The first step was to calculate the cost of the materials and fabrication. The second step was to calculate the machine operating cost. In order to evaluate the financial viability of the machine, three parameters computed and analyzed. Also, a comparison between the manual operation cost and the mechanical operation cost is conducted. These costs include depreciation (D), annual capital interest taxes (I), housing and insurance cost (THI), repair and maintenance cost $(\mathrm{R})$, fuel cost $(\mathrm{F})$, lubrication cost (Lc), and labor cost (L).

$$
\mathrm{Tc}=\frac{[(\mathrm{D})+(\mathrm{L})+(\mathrm{THD})]+[(\mathrm{R})+(\mathrm{F})+(\mathrm{Lc})+(\mathrm{L})]}{\mathrm{na}}
$$

Where: $\mathrm{Tc}=$ Total cost for study machine and tractor $(\mathrm{L} . \mathrm{E} / \mathrm{h})$ and na=Annual working hours $=500$ (h/year).

$\mathrm{Tc}=\frac{\left[\left(\frac{P c-\mathrm{Sv}}{\mathrm{Y}}\right)+\left(\frac{P c+\mathrm{Sv}}{2} x \frac{i}{100}\right)+(0.02 \mathrm{Pc})\right]+\left[\left(\frac{P c \times \mathrm{rc}}{\mathrm{Y}}\right)+(\mathrm{fc} \times \mathrm{fp})+(\mathrm{Lc})+(\mathrm{Nix} \mathrm{Lx} \mathrm{n})\right]}{\mathrm{na}}$
Where: $\mathrm{Pc}=$ Machine manufacturing price or tractor price (L. E), $\mathrm{Sv}=$ Salvage value $=5 \%$ from the machine manufacturing price or tractor $(\mathrm{L} . \mathrm{E}), \mathrm{Y}=$ Machine age $=5$ years for machine and 10 years for tractor, $i=$ Interest rate $=14 \%, r c=$ Coefficient of repair and maintenance $=1$ for tractor, 0.6 for the machine, $\mathrm{fc}=$ Actual fuel consumption=measured $(1 / \mathrm{h}), \mathrm{fp}=$ Fuel price $=6.75(\mathrm{~L} . \mathrm{E})=$ for diesel fuel, Lc=Lubrication $\cos \mathrm{t}=14 \%$ of fuel cost, $\mathrm{Ni}=$ Number of labors=Mulching crew (one labor), $\mathrm{L}=$ Labor cost $=120$ L.E/day, day ( 7 hours) (L.E/h), n=Annual working days $=(500 / 7)$ and na $=$ Annual working hours $=500, \mathrm{~h} /$ year.

Also, the cost was calculated for laying plastic film and drip irrigation pipes under soil surface traditionally. This traditional method includes using a traditional digging machine to dig the soil to the required depths after that laying plastic film and drip irrigation pipes subsurface manually, then backfill these digs by using digging machine. The manual laying of plastic film and drip irrigation pipes under soil surface need seven workers, three workers for spreading the plastic film, one worker for filling plastic bags and put them on the top of the roll to prevent it from fly by wind and three workers to lay subsurface drip irrigation pipes. This process needs about an average of 21 hours/hectare ( 7 hours work in day) this means that the one hectare needs three days' work.

(ii). Total Cost Per Unit Area

Total cost per unit area was determined as follows:

$$
\mathrm{TCA}=\frac{\mathrm{C}}{\mathrm{AFC}}
$$

Where: $\mathrm{TCA}=$ Total cost per unit area (L.E/ha), $\mathrm{AFC}=$ Actual field capacity $(\mathrm{ha} / \mathrm{h})$ and $\mathrm{C}=$ Hourly cost (L.E/h).

\section{Results and Discussion}

\subsection{Actual Field Capacity and Field Efficiency}

The Figure 14 showed that performance evaluation of developed machine by measuring actual field capacity AFC and field efficiency FE. Both of AFC and FE of machine increased by the seam percentage about of $5 \%$ when carried out ridges cultivation system compared to flat soil. Also increasing both of AFC and FE by the seam percentages about of $3 \%$ and $6 \%$ when decreasing aspect ratio from $4: 1$ to 3:1 and 2:1 respectively. On the other hand, AFC and FE increased by the seam percentages about of 3\% and $7 \%$ when plastic laying depth decreasing from $40 \mathrm{~cm}$ to $30 \mathrm{~cm}$ and 20 $\mathrm{cm}$ respectively. This may be due to the fact that, the laying plastic film at big aspect ratio and high laying depth caused decreasing in the distance covered by the machine per unit time as a result, AFC and FE decreased. In general, the highest values of AFC and FE of machine were $0.194 \mathrm{ha} / \mathrm{h}$ and $90 \%$ respectively, at treatment ridge system, aspect ratio $2: 1$ and $20 \mathrm{~cm}$ plastic laying depth (R-A1-D1). While the lowest values of AFC and FE of machine were $0.166 \mathrm{ha} / \mathrm{h}$ and $77 \%$ respectively, at treatment flat soil, aspect ratio $4: 1$ and $40 \mathrm{~cm}$ plastic laying depth (F-A3-D3). 

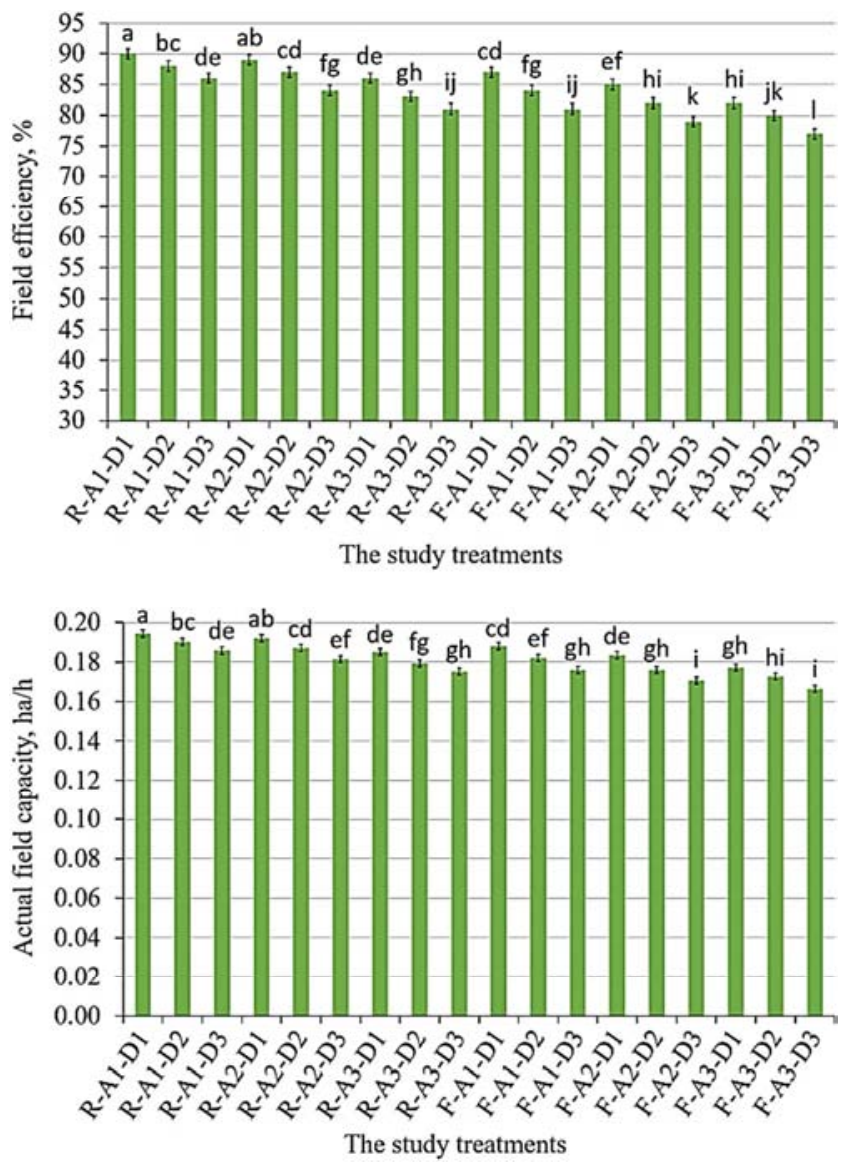

Figure 14. Effect of study treatments ( $R$ - ridges cultivation system, $A$ - aspect ratio, $D$ - plastic laying depth and $F$-flat soil system) on actual field capacity and field efficiency. Values followed by different letters are significantly different at $p<0.05$ according to the LSD test. Error bars show the standard deviation among the repetitions $(n=3)$. LSD for actual field capacity $=0.0031$ and for field efficiency $=1.3759$.

\subsection{Pulling Force and Fuel Consumption}

Figure 15 showed the significant effect of study treatments on pulling force PF and fuel consumption FC. Where PF and FC increased with flat system about of $33 \%$ and $32 \%$ respectively, compared to ridges system. This may be due to the fact that, when carried out the ridges system the board wing of machine was opened so that the soil which cumulative by machine exit in easy to build ridges which decreased soil resistance. But when carried out the flat soil system the board wing of machine was closed so that the soil which cumulative by machine moved with machine to levelling soil surface which increased soil resistance. The aspect ratio of $4: 1$ caused increasing of PF about of $11 \%$ and $24 \%$ and $\mathrm{FC}$ about of $10 \%$ and $22 \%$ compared to $3: 1$ and $2: 1$ respectively. This may be due to the fact that, when aspect ratio increased the digging width increased so that soil resistance increased. Increasing of plastic laying depth from $20 \mathrm{~cm}$ to $30 \mathrm{~cm}$ and $40 \mathrm{~cm}$ caused increasing of PF about of $17 \%$ and $49 \%$ respectively, and FC about of $16 \%$ and $44 \%$ respectively. This may be due to the fact that, when digging depth increased the weight of soil increased so that soil resistance increased. In general, the highest values of $\mathrm{PF}$ and $\mathrm{FC}$ were $26 \mathrm{kN}$ and $27 \mathrm{l} / \mathrm{h}$ respectively, at treatment flat soil system, aspect ratio $4: 1$ and $40 \mathrm{~cm}$ plastic laying depth (F-A3-D3). While the lowest values of $\mathrm{PF}$ and $\mathrm{FC}$ were $11 \mathrm{kN}$ and $12 \mathrm{l} / \mathrm{h}$ respectively, at treatment ridges system, aspect ratio $2: 1$ and $20 \mathrm{~cm}$ plastic laying depth (R-A1-D1).
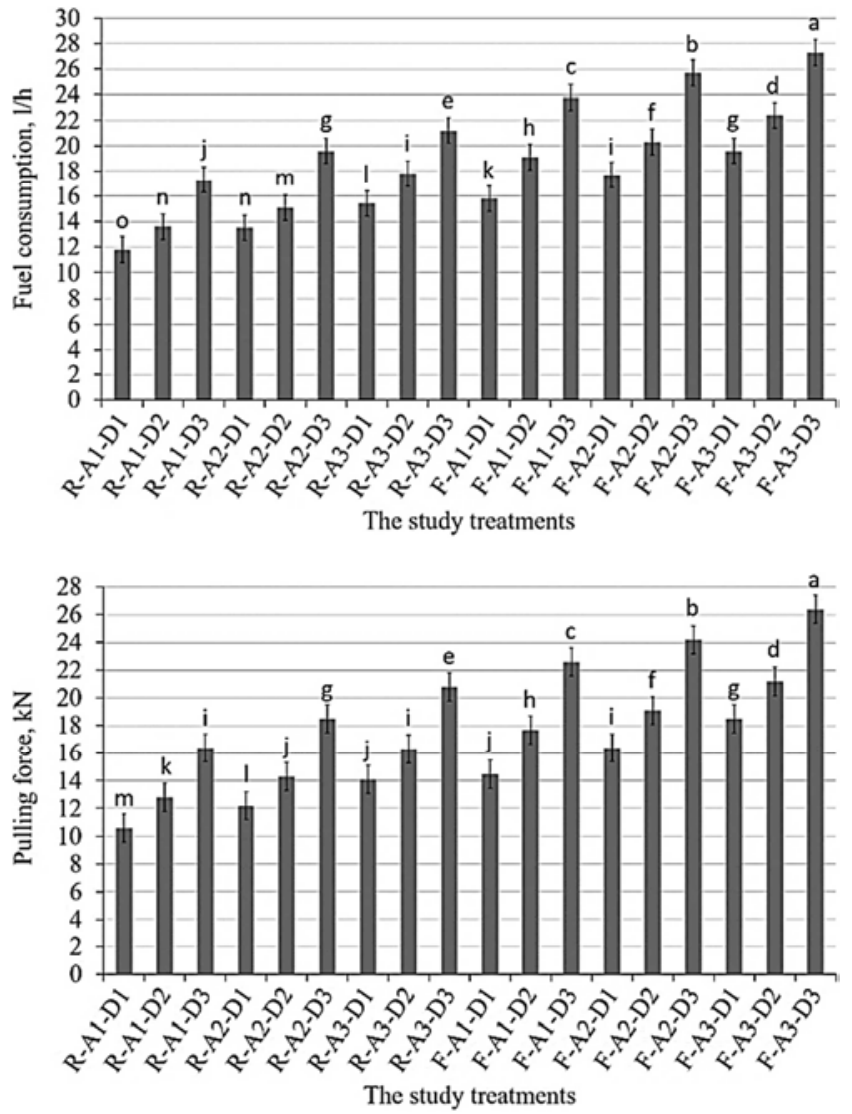

Figure 15. Effect of study treatments (R-ridges cultivation system, $A$ - aspect ratio, $D$ - plastic laying depth and $F$ - flat soil system) on pulling force and fuel consumption. Values followed by different letters are significantly different at $p<0.05$ according to the LSD test. Error bars show the standard deviation among the repetitions $(n=3)$. $L S D$ for pulling force $=0.3837$ and for fuel consumption $=0.2366$.

\subsection{Total Water Stored and Water Consumption Use}

The results in Figure 16 showed that total water stored TWS and water consumption use WCU increased about of $8 \%$ and $9 \%$ respectively, when applying ridges system compared to flat soil system. This may be due to the fact that, in ridges system the machine gathers the soil and raised it to build ridges which characteristic of good aggregate to lead to increasing of water stored. But in flat soil the machine digs soil to buried plastic film then filling it and levelling soil surface which caused compaction the soil lead to decreasing water stored. Aspect ratio of $4: 1$ caused increasing of TWS about of $10 \%$ and $21 \%$ and WCU about of $13 \%$ and $26 \%$, compared to $3: 1$ and 2:1 respectively. This may be due to the fact that, when aspect ratio increases the width of plastic membrane increased which lead to increasing stored water. Plastic laying depth of $40 \mathrm{~cm}$ caused an increasing of TWS about of $8 \%$ and $14 \%$ and WCU 
about of $9 \%$ and $17 \%$ compared to $30 \mathrm{~cm}$ and $20 \mathrm{~cm}$ respectively. This may be due to the fact that, when plastic laying depth increases the soil volume between plastic membrane and soil surface increased which lead to increasing stored water. In general, TWS and WCU increased about of $49 \%$ and $53 \%$ respectively, when using plastic membrane compared to without using plastic membrane. The best treatment which achieved the highest values of TWS and WCU about of $2968 \mathrm{~m}^{3} / \mathrm{ha}$ and $2434 \mathrm{~m}^{3} /$ ha respectively, was ridges system, aspect ratio $4: 1$ and $40 \mathrm{~cm}$ plastic laying depth R-A3-D3. While the lowest values of TWS and WCU about of $2017 \mathrm{~m}^{3} / \mathrm{ha}$ and $1489 \mathrm{~m}^{3} / \mathrm{ha}$ respectively, was flat soil, aspect ratio 2:1 and $20 \mathrm{~cm}$ plastic laying depth F-A1-D1.
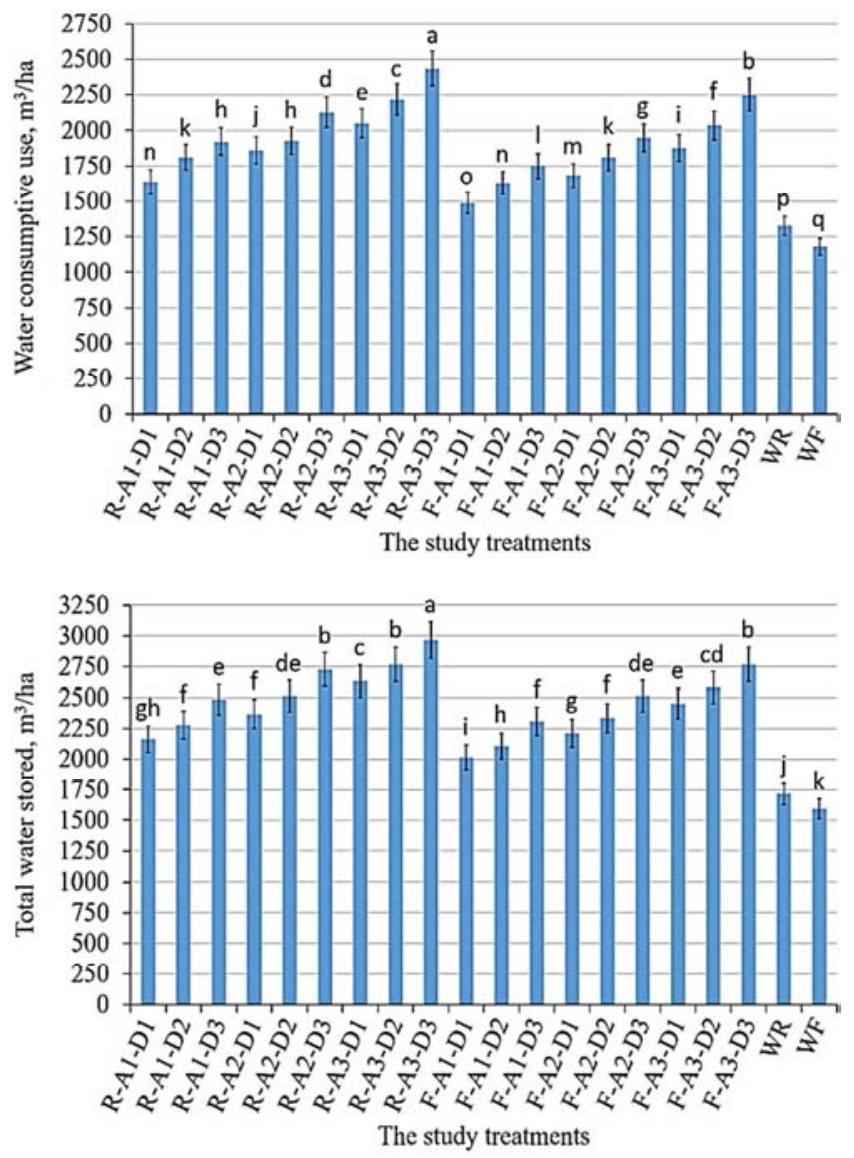

Figure 16. Effect of study treatments (R-ridges cultivation system, A- aspect ratio, D- plastic laying depth, F-flat soil system, WR-ridges system without plastic film and WF- flat system without plastic film) on total water stored and water consumption use. Values followed by different letters are significantly different at $p<0.05$ according to the LSD test. Error bars show the standard deviation among the repetitions $(n=3)$. LSD for total water stored $=67.578$ and for water consumption use $=10.85$.

\subsection{Water Stored Efficiency and Water Consumption Use Efficiency}

The study treatments had significant effect on water stored efficiency WSE and water consumption efficiency WCE as shown in Figure 17. The WSE and WCE increased about of 8\% and $9 \%$ respectively, when applying ridges system compared to flat soil system. Aspect ratio of 4:1 caused increasing of WSE about of $10 \%$ and $21 \%$ and WCE about of $13 \%$ and $26 \%$ compared to $3: 1$ and 2:1 respectively. Plastic laying depth of $40 \mathrm{~cm}$ caused an increasing of WSE about of $8 \%$ and $14 \%$ and WCE about of $9 \%$ and $17 \%$ compared to $30 \mathrm{~cm}$ and $20 \mathrm{~cm}$ respectively. In general, TWS and WCU increased about of $49 \%$ and $53 \%$ respectively, when using plastic membrane compared to without using plastic membrane. The best treatment which achieved the highest values of WSE and WCE about of $88 \%$ and $72 \%$ respectively, was ridges system, aspect ratio $4: 1$ and $40 \mathrm{~cm}$ plastic laying depth R-A3-D3. While the lowest values of WSE and WCE about of $60 \%$ and $44 \%$ respectively, was flat soil, aspect ratio $2: 1$ and $20 \mathrm{~cm}$ plastic laying depth F-A1-D1.
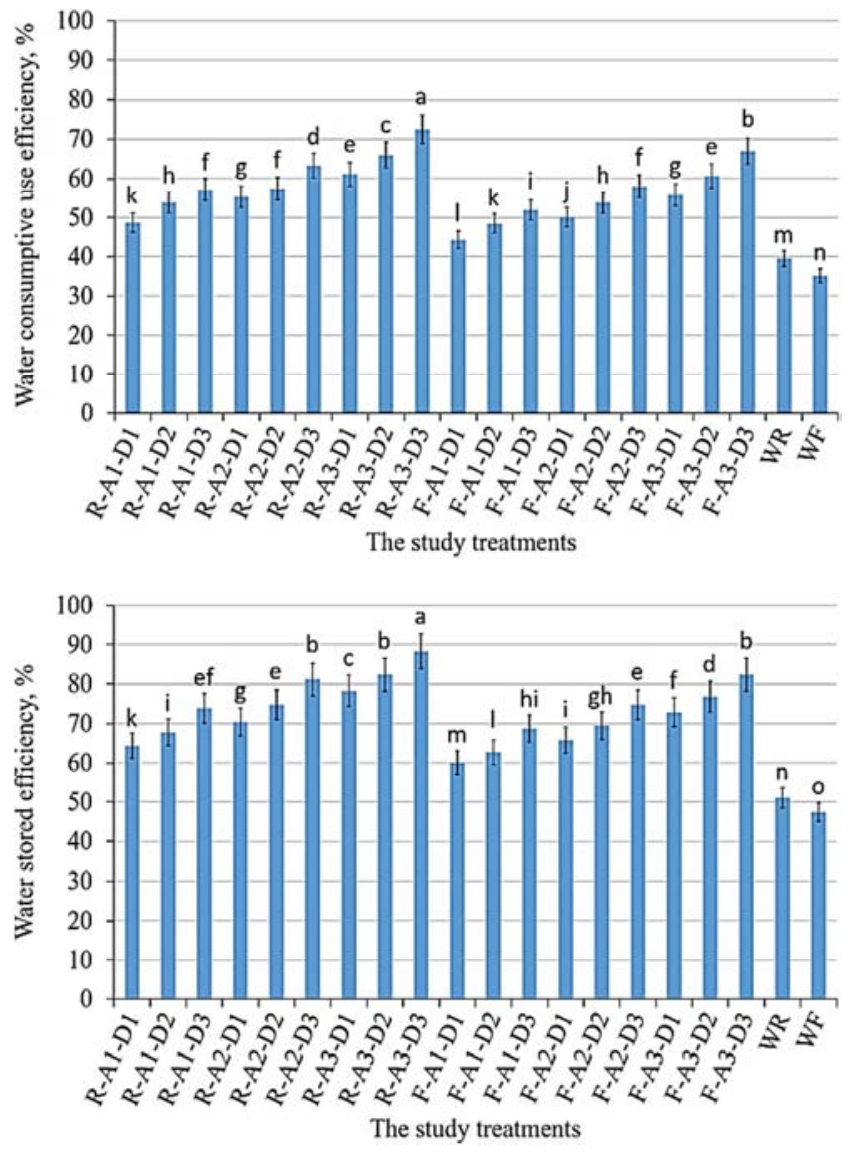

Figure 17. Effect of study treatments (R-ridges cultivation system, A- aspect ratio, D- plastic laying depth, F- flat soil system, WR- ridges system without plastic film and WF- flat system without plastic film) on water stored efficiency and water consumption use efficiency. Values followed by different letters are significantly different at $p<0.05$ according to the LSD test. Error bars show the standard deviation among the repetitions $(n=3)$. LSD for water stored efficiency=1.1595 and for water consumption use efficiency $=0.8765$.

\subsection{Faba Bean Grain Yield and Productivity of Irrigation Water}

Figure 18 showed that Faba bean grain yield FGY and productivity of irrigation water PIW increased by the seam percentage about of $7 \%$ for ridges system compared to flat soil system. Also, FGY and PIW increased by the seam percentage, about of $7 \%$ when aspect ratio increased from $2: 1$ to $3: 1$ and increased by the seam percentage, about of $14 \%$ 
when aspect ratio increased from 2:1 to $4: 1$. Data showed that when plastic laying depth increased from $20 \mathrm{c}$ to $30 \mathrm{~cm}$ FGY and PIW increased by the seam percentage, about of 5\% and increased by the seam percentage, about of $11 \%$ when plastic laying depth increased from $20 \mathrm{~cm}$ to $40 \mathrm{~cm}$. Applying SWRT system caused increasing of FGY and PIW by the seam percentage, about of $50 \%$ compared to no applying SWRT system. The best treatment which achieved the highest values of FGY and PIW about of $4.768 \mathrm{Mg} / \mathrm{ha}$ and $1.42 \mathrm{~kg} / \mathrm{m}^{3}$ respectively, was ridges system, aspect ratio $4: 1$ and $40 \mathrm{~cm}$ plastic laying depth R-A3-D3. While the lowest values of FGY and PIW about of $3.476 \mathrm{Mg} / \mathrm{ha}$ and 1.03 $\mathrm{kg} / \mathrm{m}^{3}$ respectively, was flat soil, aspect ratio $2: 1$ and $20 \mathrm{~cm}$ plastic laying depth F-A1-D1.
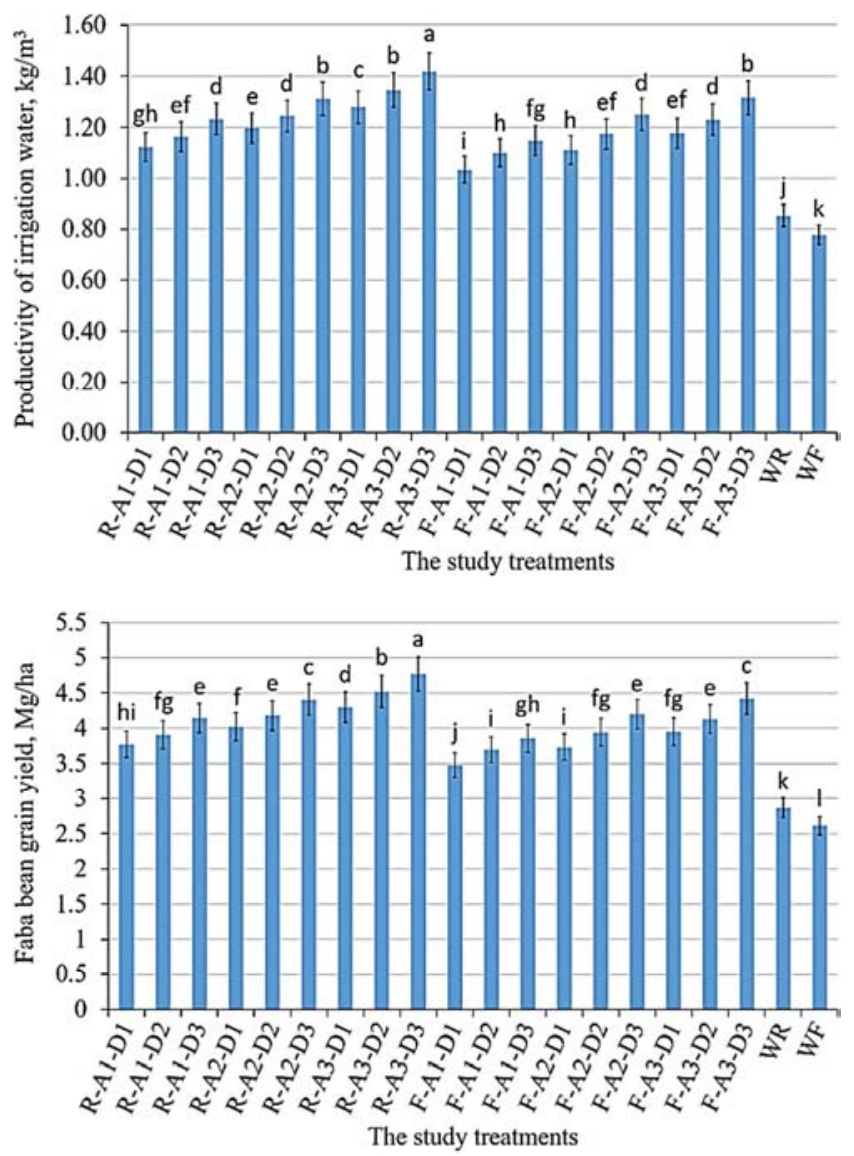

Figure 18. Effect of study treatments (R- ridges cultivation system, A- aspect ratio, D- plastic laying depth, F-flat soil system, WR- ridges system without plastic film and WF- flat system without plastic film) on Faba bean grain yield and productivity of irrigation water. Values followed by different letters are significantly different at $p<0.05$ according to the LSD test. Error bars show the standard deviation among the repetitions $(n=3)$. LSD for Faba bean grain yield $=0.0939$ and for productivity of irrigation water $=0.02897$.

\subsection{Total Cost}

Figure 19 showed that the cost of carried out SWRT system with flat soil increased about of $8 \%$ compared to the ridges. When aspect ratio increased from $2: 1$ to $3: 1$ the cost increased about of $4 \%$ and increased about of $7 \%$ when aspect ratio increased from $2: 1$ to $4: 1$. The cost increased about of $4 \%$ and $8 \%$ when increasing plastic laying depth from $20 \mathrm{~cm}$ to $30 \mathrm{~cm}$ and $40 \mathrm{~cm}$ respectively. Installing SWRT system by developed machine decreased the total cost about of $74 \%$ compared of traditional method. The best treatment which achieved the lowest cost about of $1030 \mathrm{~L}$.E/ha was using developed machine at ridge system, 2:1 aspect ratio and $20 \mathrm{~cm}$ plastic laying depth (R-A1-D1). But the highest cost about of $1279 \mathrm{~L}$.E/ha was using developed machine at flat soil, $4: 1$ aspect ratio and $40 \mathrm{~cm}$ plastic laying depth (FA3-D3).

\subsection{Machine Efficiency for Laying Plastic Film and Drip Irrigation Pipes Under Soil Surface}

Figure 20 presented the efficiency of machine for laying plastic film which expressed about it by $92 \%$ depth of plastic film efficiency, $95 \%$ width of plastic film efficiency and $91 \%$ height of plastic film efficiency. Also, the efficiency of machine for laying drip irrigation pipes was $96 \%$.

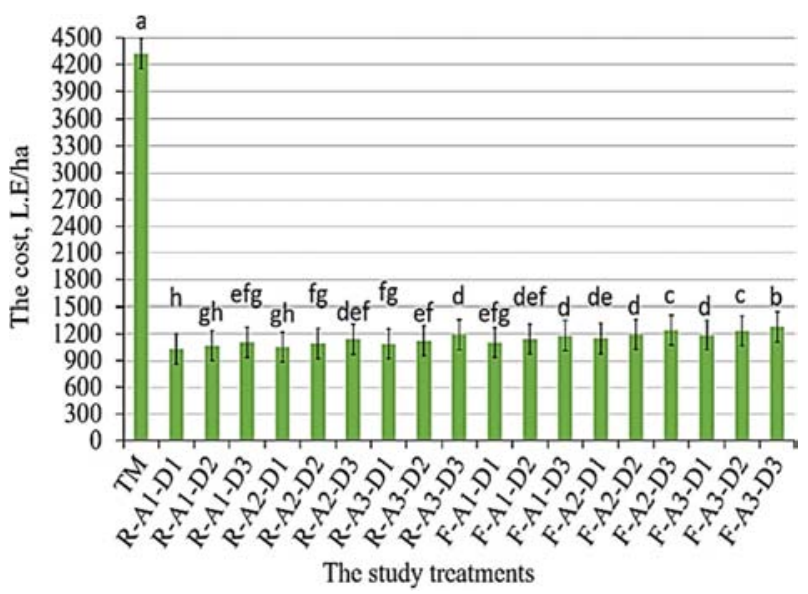

Figure 19. Effect of study treatments ( $R$ - ridges cultivation system, A-aspect ratio, D- plastic laying depth, $F$-flat soil system and TM-traditional method) on total cost. Values followed by different letters are significantly different at $p<0.05$ according to the LSD test. Error bars show the standard deviation among the repetitions $(n=3)$. LSD for total cost $=35$.

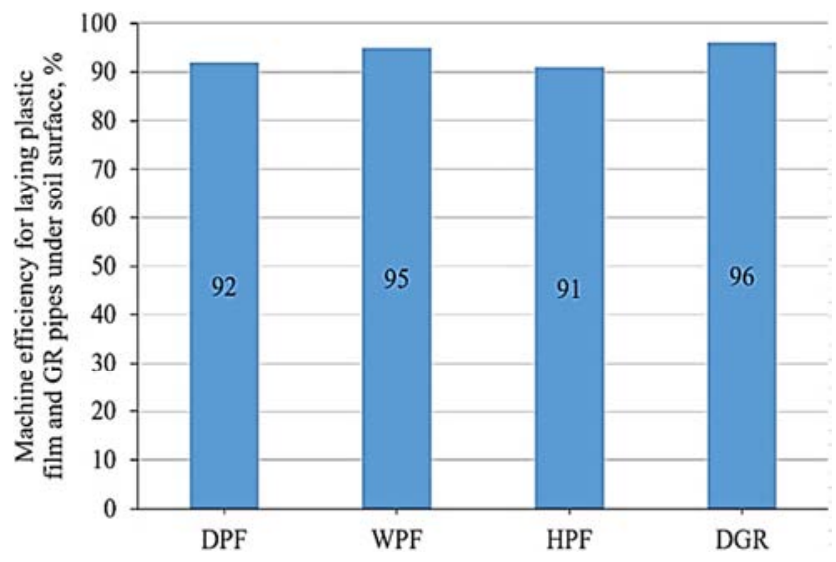

Figure 20. Effect of, DPF-depth of plastic film, WPF-width of plastic film, $H P F$ - height of plastic film and DGR- depth of GR pipes irrigation on machine efficiency.

\section{Conclusion}

Increasing water productivity is a major goal in modern 
agriculture and accomplishes to maintain food security and agriculture sustainability. So that using the subsurface water retention technology (SWRT) achieves this goal. But carry out this technology is very difficult. Therefore, the developed machine was manufactured and evaluated by field experiment which, concluded as the following:

1. The ability of machine to implement SWRT system under two cultivation methods (ridges and flat soil).

2. The ability of machine to install plastic membrane at different depths below soil surface and different aspect ratio.

3. The ability of machine to lay subsurface drip irrigation pipes with installing plastic membrane in seam time which, saved the effort, time and cost.

4. The cost of carried out SWRT system by developed machine decreased about of $74 \%$ compared to traditional method.

5. The best treatment from field experiment which, achieved the highest total water stored, water consumptive use and Faba bean grain yield about of $49 \%, 53 \%$ and $50 \%$ was installing plastic membrane at ridges cultivated system, aspect ratio $4: 1$ and $40 \mathrm{~cm}$ plastic laying depth compared to no installing plastic membrane.

6. Finally, it is suggested that using SWRT membrane is a scientific method to improve condition of sandy soils and arid areas.

\section{Recommendations}

For further studies in the same topic the following recommendations were suggested:

1. Study the possibility of utilizing SWRT in strategic crops for example wheat, barley and rice in order to increase the national product and support of agriculture in Egypt.

2. Study the possibility of using SWRT to rain water harvesting in arid areas especially in the northwest coast in Egypt.

\section{References}

[1] Mckenna, T. 2012. Feed the future deputy coordinator for development, Report before the senate foreign relations international development subcommittee. November 28, 2012.http://www.usaid.gov/newsinformation/congressionaltestimony/testimony-tjada mckenna-feed future deputycoordinator.

[2] Clay, J. 2004. World Agriculture and the Environment: A Commodity-by-Commodity Guide to Impacts and Practices. Chicago: Island Press.

[3] Shorafa, M. 1987. [Perlite and Hydroplas effect on porosity, soil permeability and holding capacity]. MSc thesis of soil science, Tehran University, Iran [in Persian].

[4] Lamm, F. R., and Trooien, T. P. 2002. Subsurface Drip Irrigation for Corn Production: A Review of 10 Years of Research in Kansas, Irrigation Science, Vol. 22, no. (3-4), pp. 195-200.
[5] Skaggs, T. H., Trout, T. J., Simunek, J. and Shouse, P. J. 2004 Comparison of Hydrus -2D Simulations of Drip Irrigation with Experimental Observations, Journal of Irrigation and Drainage Eng., Vol. 130, PP. 304-310.

[6] Lin, M. Z., Wang, J. and Zhou, L. M. 2006. Impact of sub groove water-saving on growth and yield of Triticum aestivum. Acta Pratacul. Sin. 15, 52-58 (in Chinese with English abstract).

[7] Sivapalan, S. 2006. Some Benefits of Treating a Sandy Soil with a Crosslinked Type Polyacrylamide, Australian Journal of Experimental Agriculture, Vol. 46, No. 4, PP. 579-584.

[8] Ismail S. M. and Ozawa, K. 2007. Improvement of crop yield, soil moisture distribution and water use efficiency in sandy soils by clay application. Applied Clay Science 37 (1): 81-89.

[9] Shahid S. A., Qidwai, A. A., Anwar, F., Ullah, I. and Rashid, U. 2012. Improvement in the water retention characteristics of sandy loam soil using a newly synthesized poly (acrylamideco-acrylic acid)/A1ZnFe2O4 superabsorbent hydrogel nanocomposite material. Molecules 17: 9397-9412.

[10] Ahmed T. F., Hashmi, H. N., Ghumman, A. R. and Sheikh, A. A. 2012. Performance assessment of surface and subsurface drip irrigation system for date palm fruit trees. African Journal of Agricultural Research 7 (10): 1542-1549.

[11] Yang, Z., Smucker, A. J. M., Jiang, G. and Ma, X. 2012. Influence of the membranes on water retention in saturated homogeneous sand columns. International Symposium on Water Resource and Environmental Protection (ISWREP), 1590-1593.

[12] Demirel, K., and Kavdir, Y. 2013. Effect of soil water retention barriers on turfgrass growth and soil water content. Journal of Irrigation Science 31: 689-700.

[13] Descheemaeker, L., Bunting, S. W., Bindraban, P., Muthuri, C., Molden, D., Beveridge, M., Brakel, M. V., Herrero, M., Clement, F., Boelee, E. and Jarvis, D. I. 2013. Managing Water and Agroecosystems for Food Security, Increasing Water Productivity in Agric., Chap 8.

[14] Cameron, L., Smucker, A. and Walsh, K. 2013. Revolutionary Technology Aids Thirsty Crops during Drought. Michigan State University Today.

[15] Smucker, A. J. M. 2014a. Improved water policies and new technology will promote greater food and cellulosic biomass production and reduce competition for water. In: food safety, security and defense: focus on food and water. Institute on Science for Global Policy. Pp: 60-68.

[16] Kavdir, Y., Zhang, W., Basso, B. and Sumcker, A. J. 2014. Development of a new soil water retention technology for increasing production and water conservation. J. Soil and Water Conservation. 69 (5): 154-160.

[17] Smucker, A. J. M., Kavdir, Y. and Zhang, W. 2014. Root zone soil water retention technology: a historic review and modern potential, Soil Science Society of America Journal (in review).

[18] Berhanu, S., Guberand, A. and Smucker, A. 2014. Improving irrigation efficiency of sandy soils by subsurface water retaining membranes, Department of Crop, Soil and Microbial Sciences, Geophysical Research Abstracts. Vol. 16, EGU2014-6756, EGU General Assembly, Michigan State University, USA. 
[19] Andrey, K. G., Alvin, J. M. S., Samrawi, B. and James, M. L. M. 2015. Subsurface Water Retention Technology Improves Root Zone Water Storage for Corn Production on Coarse Textured Soils, Vadose Zone Journal, Vol. 14, No. 7, PP. 1-13.

[20] Guber Andrey K., Berhanu Samrawi A. J. M. S. and Miller James, M. L. 2015. Subsurface Water Retention Technology Improves Root Zone Water Storage for Corn Production on Course Textured Soils, Vadose Zone Journal, Soil Science Society of America, July, 14 (7).

[21] Smuker, A. J. 2016. A Transforming Soil Water Retention Technology that Eradicates Drought and Increases Crop Resilience to Changing Climates, 5th International Conference on Agric. \& Horticulture, Vol. 5, No. 2, PP. 24.

[22] Smucker, A. J. M., Yang, Z., Guber, A. K., He, X. C., Lai, F. H. and Berhanu, S. 2016. A new Revolutionary Technology to Feed Billions by Establishing Sustainable Agriculture on Small and Large Landscapes Including Urban Regions Globally, International Journal of Development Research, Vol. 06, Issue, 10, pp. 9596-9602.

[23] Isa, H. A. M. 2016. Effect of SWRT technology on water productivity of tomato and Chili pepper in sandy soil under water scarcity, $\mathrm{PhD}$ Thesis College of Agriculture/ Baghdad University, Iraq.

[24] Amirpour, M., Shorafa, M., Gorji, M., and Naghavi, H. 2016. Effect of subsurface water retention using polyethylene membranes with surface mulch and irrigation on moisture, temperature and salinity of sandy soil of an arid region in Iran. Advances in Environmental Sciences-International Journal of the Bio flux Society, V., 8, Issue 1.

[25] AL-Rawi, S. S., Aoda, M. I. and Ati, A. S. 2017. The Role of Subsurface Water Retention Technology (SWRT) for Growing Chili Pepper in Iraqi Sandy Soils, Journal of Environment and Earth Science, Vol. 7, No. 1. pp. 82-89.

[26] Hommadi, A. H. 2018. Evaluating the use of Subsurface Water Retention Technology MSc thesis in Water Resource department/College of engineering/ Baghdad University, Iraq.

[27] Salim, A. H. 2018. Improving Field Water Use Efficiency by Using Subsurface Water Retention Technology MSc thesis in Water Resource department/College of engineering/ Baghdad University, Iraq.

[28] Almasraf, S. A. and Salim, A. H. 2018. Improvement of the Water Use Efficiency and Yield of Eggplant by using Subsurface Water Retention Technology, Journal of Engineering. Vol. 24. No. 3. March. Baghdad/Iraq.

[29] Hommadi, A. H. and Almasraf, S. A. 2018. Subsurface Water
Retention Technology Improves Water Use Efficiency and Water Productivity for Hot Pepper, Journal University of Kerbala. Vol. 16. No. 1. Kerbala/Iraq.

[30] Hommadi, A. H. and Almasraf, S. A. 2019. Water Retention Technology under Crop's Root Zone a Toll to Enhance Water Use Efficiency and Economic Water Productivity for Zucchini, Journal of Engineering. Vol. 25. No. 6. Baghdad/Iraq.

[31] Doughty, J. and Walker, A. 1982. Legumes in humen Nutrition. 20: 152 .

[32] Sharaan, A. N, Ekram, A., Megawer, H. A. S. and Hemida, Z. A. 2004. Seed yield, yield components and quality character as affected by cultivars, sowing dates and planting distances in faba bean. Bull. Agric. Econ. Min. Agric. Egypt. http://fayoum.edu.eg/Agriculture/Crops/pdf/Fabapaper3.pdf.

[33] El-Galaly Ola A. M., Abou-Mostafa, R. A. I., Nagwa, A. M. and Mahmoud, M. A. 2008. Response of two faba bean (vicia faba L.,) promising lines and Sakha 3 cultivar to different sowing dates and densities J. Agric. Res., Kafr El-Sheikh Univ., 34: 647-661.

[34] El-Saady, A. S. M., El-Atawy, G. S. and Atia, R. H. 2011. Effect of furrow spacing and phosphorus fertilization treatments on faba bean yield, nutrients content and some water relationships. J. Soil Sci. and Agric. Eng., Mansoura Univ., Vol. 2 (5): 597-610.

[35] Andreas P. S. and Karen, F. 2002. Crop Water Requirements and Irrigation Scheduling; Irrigation Manual Module 4.

[36] Kepner, R. A., Bainer, R. and Barger, E. L. 1978. Principles of farm machinery. Third Edition. A VI Publishing Company, Inc. Westport, Connecticut. U.S.A. P: 186.

[37] James, L. G. 1988. Principles of farm irrigation system design. John Willey \& Sons (ed.), New York, pp. 543.

[38] Hansen, V. W., Israelsen, O. W. and Stringharm, G. E. 1979. Irrigation principles and practices. $9^{\text {th }}$ ed., John Willey and Sons Inc., New York, USA.

[39] Israelsen, O. W. and Hansen, V. E. 1962. Irrigation principles and practices. $3^{\text {rd }}$ Ed. John Willey and Sons Inc., New York.

[40] Ali, M. H., Hoque, M. R., Hassan, A. A. and khair, A. 2007. Effects of deficit irrigation on yield, water productivity and economic returns of wheat. Agricultural water management, 92 (3): 151-161.

[41] Oida, A. 1997. Using personal computer for agricultural machinery management. Kyoto University. Japan. JICA publishing. 